\title{
Zonal ecosystems of Volga river basin under global warming: prognostic and paleogeographical scenarios
}

\author{
Erland G. Kolomyts \\ Institution of Ecology of the Volga River Basin, Russian Academy of Sciences, D-2-82, Pushchino, Moscow region, 142290, Russia
}

Email address:

egk2000@mail.ru (E. G. Kolomyts)

\section{To cite this article:}

Erland G. Kolomyts. Zonal Ecosystems of Volga River Basin under Global Warming: Prognostic and Paleogeographical Scenarios, American Journal of Environmental Protection. Vol. 2, No. 1, 2013, pp. 10-36. doi: 10.11648/j.ajep.20130201.12

\begin{abstract}
The concept of landscape-ecological prognoses for temperate forest ecosystems in light of forthcoming climate changes is presented. Predictive analysis is based on empirical-statistical modeling ecosystems and on descriptions of their space organization. The boreal bioclimatic ecotone of the Volga river basin is used as an example for carry out the experience of analytical and cartographic prognostic scenario modeling of the nearest and distant future for given ecoregion and their paleogeographical analogs in upper Pleistocene and Holocene. The mechanisms of local and regional response of forest ecosystems to the anticipated global warming in the 21 st centuries have been assessed, according to global climate prediction model GISS-1993 (modernized version 2003-2006). The quantitative methods of landscape-ecological forecasts have been developed by the author are described in detail. A progressively increasing thermo-arid bioclimatic trend is predicted, with a general shift of zonal boundaries to the north and with the corresponding changes in the water regime and plant cover structure of the territory. An analogous picture results from paleo-prognostic reconstructions of the optima of Holocene and Mikulino interglacial period.
\end{abstract}

Keywords: Global Changes, Empirical-Statistical Modeling, Landscape-Ecological Prognosis, Paleoreconstruction

\section{Introduction. Regional Ecology and Problem of Global Changes}

Fundamental problems of ecology and geography include, as is known, the problem of global changes, which is the core of "International Geosphere-Biosphere Program" [1]. The Program is designed for a long-term outlook and envisages development of scenarios for the nearest future of biosphere in terms of physical models describing basic processes and events. One of the most dynamic natural processes on the planetary scale, which efficiently influenced biosphere evolution in the past and determine its condition in the future, are changes in the global climate caused by changed chemical composition of atmosphere, with the corresponding demonstration of greenhouse effect. The coming global climatic changes will be associated first of all with technogenic growth of the content of $\mathrm{CO} 2$ and other greenhouse gases in atmosphere, which may disturb the natural carbon cycle in biosphere and lead to largescale ecological consequences, including reorganization of landscape-zonal structure of entire continents [2-4].

Thus, problem of global changes has the large enough practical aspect. Ecological safety of large territorial subunits of the continental biosphere significantly depends on the state of the zonal-regional types of natural ecosystems, first of all forest cover. Therefore the problem of maintenance of forest ecosystems and reproduction of forest resources on the southern boundary of temperate forest zone, where forest communities are present in the states close to critical, is among the fundamental ecological problems. It has always been of high priority for the East-European countries, where the wide transitional zone from forest to steppe, i.e. the zonal forest-steppe ecotone, is an industrial and demographical core of this large region. At the moment, more and more significance in the solution of this problem is gained by the questions of stability of natural ecosystems as a natural-historical basis of stable development of the region.

As is known, global geosystem monitoring is most upto-date and actually realizable on the scale of individual ecological regions [5]. However, natural processes and events on the regional hierarchic level are characterized by the greatest diversity and high discreteness [6], therefore the regional response of global climatic changes inevitably takes the form of multiple reactions of vegetation, soils and landscapes as a whole to background climatic signals. So 
far there is no any distinct notion of this multiplicity, because the measure of sensitivity of soil-biotic components to climatic changes in different zonal-climatic and geomorphological conditions has not yet been estimated.

The known to date prognostic-ecological developments are, with few exceptions, of a very schematic character and aimed mainly at the assessment of general future condition of biosphere as a planetary system by quite a limited set of geophysical parameters (for the most part, air temperature and atmospheric precipitation). Accordingly, prognostic and paleogeographical maps are too small-scale and cartographic prognosis confines itself to schematic demonstration of changes in the boundaries of natural zones and areals of some forest species [7-13, etc.]. The regional level of geoecological prognoses still has not been developed enough due to insufficiency of factual material and methodical difficulties of the transfer of hydro-climatic prognosis from global to regional.

Solution of all the above problems is somehow or other associated with an integrated regional paleo-prognostic conception presented in given report as a working version. Prognostic landscape-ecological scenarios of the nearest future of biosphere and their paleogeographical analogs as a single system of global environmental changes have been developed and assessed by the example of a large region the Volga River basin, which is an economic and demographic "core" of European Russia. The main attention was paid to the mechanisms of shifts in the patterns of vegetation, soils and landscapes on the model territory under given scenarios of disturbing impacts of the climatic system, which are envisaged in the foreseeable future (to the middle of the 21 st century) and whose analogs could occur in the geological past - the optima of Mikulino (Eemian) interglacial period (near 125000 years ago) and the optima of Holocene (5-7000 y.a.). With this purpose, regional analytical and cartographic (on much vaster scale than before) prognostic models of landscape-ecological conditions have been developed, as well as models of the above two paleogeographical transects, in the light of future and past scenarios of global climatic changes.

The solution of multipurpose tasks of ecological forecasting may depend to a great extent on the results of system analysis of nature-territorial structures, which are most sensitive to external effects including anthropogenic. The scientific search in this direction focuses more and more attention on the natural boundaries - both individual and complex, where the most significant natural or anthropogenic shifts in the structure and function of geo(eco)systems are observed. Considering one or another natural boundary as a vector (connection, cascade, paradynamical, etc.) landscape system [14-17, etc.] with a clearly defined spatial polarization of its different properties, we obtain a "fast-flowing" model of state response and resistance of ecosystems to the action of certain ecological factors.

The conception of regional manifestations of global environmental changes is undoubtedly of fundamental importance for not only regional but also global ecology, because global biosphere processes and events are perceived most deeply through the level of ecological regions, which is aided by high diversity of their nature-territory structures, as well as the complexity of functioning and evolution transformations of regional ecosystems. Ecological region of the main drainage area of the Volga River basin is quite a favorable natural model for paleo-prognostic analysis, because it is entirely included into the East-European boreal ecotone - a system of close zonal boundaries, which is very sensitive to global climatic changes. Here, zonal boundaries are characterized by high dynamism, which is indicated by entire Holocene history of aboriginal flora in the Middle Belt of the Russian Plain.

At present researchers of different countries have conducted certain studies on the problem of global-climatic and most common ecological scenarios of expected changes of the environment which are powered by the accumulation of anthropogenic $\mathrm{CO} 2$ and other greenhouse gases in the atmosphere. To use these results in further scientific and practical research in the field of environmental protection, it is necessary to evaluate the common prognostic landscape-ecological situation for each continental region of the Earth. However the direct use of the global prognostic parameters for regional levels is impractical and can be in error. Global prognoses sketch the most broad outlines of possible changes of the environment and are often accompanied by schematic maps. Unfortunately the scales of such maps are too small (no more than 1: 30 $40,000,000)$ and only shifts of boundaries of nature zones are shown on them $[3,4,18]$. Ecological predictions themselves are based for the most part on the palaeogeographical reconstruction (palaeoanalogies) by a very scarce net of points with palynogical (spores and pollen) dates [19, 20], so they do not describe the regional and local diversity of ecological situations.

The greater impact appears to be in the adoption of the theoretical (calculated) estimation of global climatic changes derived from the models of general atmospheric circulation - AOGCMs [4, 21]. However special systematic difficulties emerge here. The main problem is the transformation of global climatic signals into regional and local ecological ones on a rather large scale of natural landscape types including subregional and local plant societies. Up to now, regional tests have not been carried out adequately to determine the most probable directions and relative rates of spreading of external signals both on the system of connection of the nature component and on the lines of landscape chains in space. Therefore the response of ecological (climatic) niches of these phytocoenoses to global climatic changes is not clear.

The present work is one of the experiments of the regional landscape-ecological prognosis and paleoreconstructions at a much more large scale $(1: 5-6,000,000)$. The report expounds the main statements of original geoecological concept of prediction: "Global Changes on the Regional Levels", as a basis of regional bioecological and geosystem monitoring under global anthropogenic climatic 
changes. Objects of research are forest and forest-steppe landscape-zonal systems of the headwater of the Volga River basin. The conservation and reproduction of forest resources under changing climatic conditions at the southern boundary of temperate forest zone, where forest communities are in conditions close to critical, is one of the fundamental ecological problems.

\section{Zonality as an Object of Ecological- Geographical Investigation}

The concept of integrity and continuity of geographic environment proposed by V.V. Dokuchayev [22] and then comprehensively developed and theoretically substantiated by A.A. Grigoryev [23] occupies a central place in the theory of geographic organization of terrestrial natural systems. This concept has been most fully developed in the theory of geographical zonality. It should be noted that zonality as a universal phenomenon of spatial organization of the biosphere is known to mankind since antiquity. The scientific conceptions of natural zonality were developed by more than one generation of foreign and domestic naturalists, first of all, in the field of plant geography, with the most important contributions made by A. Gumboldt, V.V. Alekhin, and H. Walter [24]. However, the theory of complex (landscape) zonality became a complete concept in the known works of V.V. Dokuchayev only about 100 years ago. He considered geographical zonality as the highest form of interdependent functioning of structural parts of the biosphere $[22,25]$. This conceptual proposition was further developed in the fundamental works [21, 22, 2630]. L.S. Berg [31, p. 210] seemed to be the first who characterized geographical zones as landscape zones, thereby emphasizing the profound unity between the concepts of "landscape" and "natural zone".

One should particularly note the close link between subsequent elaboration of the theory of zonality as a global bioclimatic phenomenon and development of landscape science and then geoecology, representing the general tendency to convergence between geography and ecology. The ecological approach substantially extended the scope of natural zonality as a traditional object of physical geography $[32,33]$. The structure and function of zonal types of landscapes and natural ecosystems, first of all the complex structure of phytobiota and its productivity, seem to be manifestations of the higher organizational form of the biosphere. We consider the phenomenon of zonality as an integral pattern of the greatest number of different but related characteristics of natural environment. This phenomenal peculiarity of zonal organizational form of the biosphere was emphasized and very figuratively stated by V.V. Dokuchayev [25, p. 320]: "You must not even expect the greater analogy, the greater parallelism, the greater connection and genetic affinity... and - even, so to say, worldwide co-assistance and love between separate elements and separate natural kingdoms...".
However, it should be mentioned that the ecological approach is rather completely realized only as applied to the two extreme structural levels of the biosphere: planetary [2, 30,34 , etc.] and local [6, 35, etc.]. The regional level is illustrated much more poorly. Here, a researcher faces an exceptionally greater territorial diversity of geosystems with the most pronounced individuality and discreteness, which complicates typification of regional geospaces and impedes application of traditional modeling methods to their investigation. Solution of the regional physicogeographical problems is most often confined to distinguishing natural regions, though it must be just the beginning but not the end of serious regional analysis. This is highly relevant, all the more so because the most of global ecological problems of today must be solved just at the regional level [36].

In accordance with the modern concepts of spatial polystructure of the biosphere and its parts $[6,37,38$, etc.], natural zones and subzones (and, accordingly, zonal ecotones) are distinguished as a certain level of the double-row hierarchical system of subplanetary and regional natural complexes, belonging to one of these rows (climatic). According to the Dokuchayev's paradigm, the zonal features of organization are more or less inherent to all levels of the hierarchy of natural complexes [39]; however, they manifest themselves to the greatest extent in the types of geographic environment [34]. L.S. Berg meant primarily a zonal type of landscape when defining landscape as “...a higher-order community ... where all parts are interrelated and orderly integrated" [26, pp. 6, 8]. Much later, this definition was filled with the ecological content [30, 40]. So, when characterizing the main trends in geosystem monitoring, I.P. Gerasimov [5] distinguished zonal categories of landscape complexes as the basic types of terrestrial natural ecosystems. He paid special attention to the balance of substances and the rate of their internal cycle as the most important parameters of total perfection of ecosystem organization and stability.

The modern theory of zonal structure of the biosphere and its parts assumes the existence of different forms of partial (component) and landscape zonality: plain (horizontal) and mountain (altitudinal), latitudinal and longitudinal, paragenetic and paradynamic [16], expositional (including circulatory, solar, and wind-driven) and the so-called dislocation zonality being a form of the most complex combination of zone forming factors [41]. In this study we will consider the properties of zonal geospace of plains that manifest themselves in territorial ordering of regional landscapes both in the "core of typicality" of natural zone, according to D.L. Armand [32], and on its periphery, including the zonal boundary.

Zonal geospaces, like other natural formations of the regional level, are conventionally distinguished by estimating the relations and interactions between system-forming factors "at the entry" (in this case, climatic factors) and by phyto- and soil-indicative characters. At the same time, the intrazonal structure of geospace remains a black box for 
researchers. It is not accidental that N.A. Solntsev commented on this matter not so long ago: "...the problem of zones as yet has been only posed but absolutely not elaborated" [39, p. 9]. What is meant here is mainly identification of the leading forms of territorial organization of zonal geospaces. When studying the causative mechanisms of attainment of some or other zonality properties by landscapes, we thereby touch upon the internal processes occurring in zonal geospaces, i.e., transform the "black box" into a gray one.

Organization of zonal geospaces is closely associated with territorial distribution and correlation of the ecological niches of natural complexes [42]. When speaking about the ecological niches of landscape systems, we imply primarily their phytocoenotic blocks, which are distributed in the zonal geospace in accordance with the climatic and edaphic niches of dominating edificatory species and communities formed by the latter. Here, it is first and foremost the question of zonal types and subzonal subtypes of plant formations, with primary vegetation being their fundamental diagnostic property.

Author concentrates upon the prognosis of the influence of the forthcoming global human changes of climate on the structure-functional states of forest ecosystem, and on the changes of landscape structure of ecoregions at the main watershed of Volga River basin, that is included in the boreal ecotone of Russian plain. Such a boundary on the territory of Eurasia is a broad transitional strip between the boreal (mainly taiga-forest) and sub-boreal (forest-steppe and steppe) belts of plant formations (Fig. 1). The frontier stretches from the Baltic Sea to the East Sayan and Lake Baikal [33] and then, after a break, to Inner Mongolia. This transcontinental boreal ecotone $[43,44]$ is a vector (connection) ecosystem of the highest, or belt, rank. On the Russian (East-European) Plain, the boreal ecotone spreads to the forest and forest-steppe ecosystems of the Volga River basin headwater. The analysis is including the zonal spaces of middle and south taiga, of mixed forest, of broadleaf forest and of forest-steppe (together with north steppe). Research region is disposed into coordinates 52-56o n. 1 . and $36-560$ e. 1 .

The above studies [44-46] have proved ample effectiveness of the methodical techniques of analysis and synthesis used in this work, as well as theoretical and practical significance of empirical generalizations. This allowed us to specify and elaborate the known postulates of the theory of biogeographical and landscape ecotones [45, 46], to offer and substantiate a conception of polymorphism of landscape-zonal systems as a new trend of complex physical geography, as well as to formulate the basic postulates of paleoprognostic conception and, on this basis, to obtain regional analytical and cartographic prognostic models of landscape-ecological conditions of the Volga river basin in the light of anticipated global climatic changes. Obviously, not all scientific-methodical and theoretical postulates are indisputable, many of them need further elaboration, but they are all the more so important since they stimulate a new scientific search. The work turned out to have many aspects so it is impossible to enumerate all results of the study performed. Let us mention only those which, in our opinion, are of the greatest methodical significance or rather novel in theoretical respect.

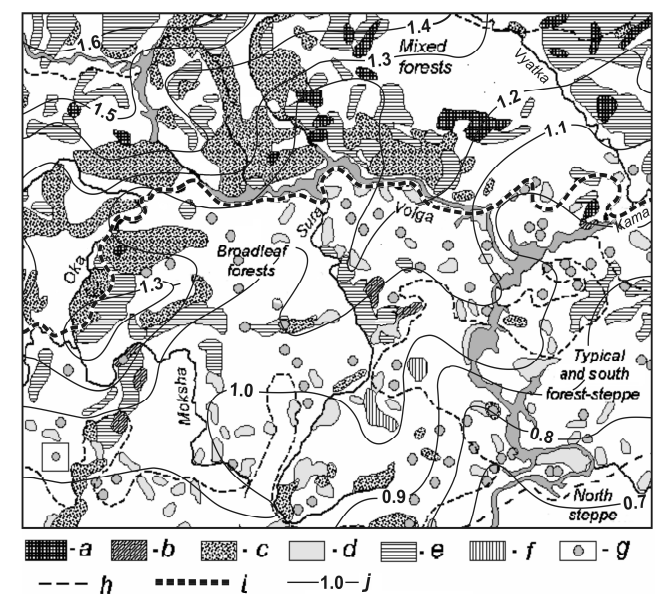

Fig. 1. Zonal-regional hydrothermal conditions and forest formations on headwater of the Volga river basin. Forests: a -fir, silver fie and black alder; $b$ - broadleaf-pine, sometimes with fir; $c$ - pine and fir-pine; $d-$ broadleaf; $e$ - birth-aspen and birth-lime; $f$ - birth and pine-birth; $g-$ extra-scale arias of broadleaf forests; $h$-boundaries between the natural zones/sub-zones; $i$ - Main Landscape Border of the Russian Plain, according to (Milkov, 1981). Other meanings: $j$ - isolines of Vysotsky-Ivanov's annual atmospheric humidify factor $F_{\text {hum }}(1)$.

Analytical and cartographic landscape-ecological paleoprognostic models for the territory of the Volga River basin made possible to establish the regularities of functional and structural response of zonal-regional ecosystems to global climatic signals, producing a development of landscapegeophysical connections that provides wider and more efficient use of the method of actualism in retrospective and numerical geoecological prognosis. The priority was given to revealing, typification and analysis of stability of climatic niches of boreal and subboreal forest ecosystems, as well as to disclosure of the mechanisms of their transformations under given theoretical (calculated) and paleogeographical scenarios of changes in the global climatic system. This pressing problem is associated with the preservation and reproduction of forest resources in the south of the boreal belt in the light of envisaged (and probably already starting) global warming.

It is need to emphasize that this research covered the questions of only structure-functional organization of natural (indigenous) plain landscapes in different zonal conditions of the temperate belt, but did not touch upon the involvement of anthropogenic geocomponents in this organization. The authors posed the problem of re-interpretation of one of the core aspects of the traditional complex physical geography: the theory of geographical zonality based on empirical modeling and system analysis. Introduction of various attributes of anthropogenic transformation of geo(eco-)systems into the models under study would so mach complicate the data matrix that the empirical models 
on their basis would lose their main property - a sufficient observability and representativeness for solution of problem posed.

\section{Empirical Grounds of Predictions and Paleogeographical Reconstruc- tions}

\subsection{Empirical Landscape-Ecological Modeling}

The problems of predictive dynamics of forest ecosystems under changing climate have been developed quite poorly as yet. The known simulation models of forest responses to climatic impacts [47-50, etc.] meet the narrow preset framework of habitat conditions, therefore the results of such modeling are insufficient for prediction of the state of forest community as a whole and do not cover the spatial diversity of succession changes under the same background influence. The local landscape-ecological prediction, which we have developed, is based on construction of discrete empirical-statistical models of natural ecosystems [43, 46, 51]. These models describe the category of selforganizing systems, which can adequately describe stabilizing selection as a response of the biota to climatic perturbations exceeding the adaptation threshold. In these models, the results of field observations are used as an empirical basis for modeling itself, rather than as reference data for testing results of calculations. This, first, minimizes the effect of the subjective factor in developing the model; second, provides a considerably higher spatial resolution than, e.g., simulation modeling; and, third, gives empirical grounds for wider geographic generalizations.

The landscape-ecological analysis has been performed using a series of empirical models: (a) informational, serving as a basis for the regional and local banks of ecological niches of geo(eco-)systems that characterizes their parametric space; (b) fuzzy set theory, describing the polysystem unit of nature-territorial organization by operations with the ecological niches as descriptive vectors. Complex interconnections were revealed and the territorial ecological space of regional ecosystems was described on the basis of information-statistical and fazzy-set-theoretical models.

\subsection{Zonal-Regional Characteristics of Bioclimatic Sys- tem}

A regional bioclimatic system - an ordered combination of territorial connections of plant cover with hydrothermal factors - was considered. The hydro-climate description of territory of the Volga River basin and its surroundings was based on 25 landscape-geophysical maps of the Volga River basin $(1: 2,500,000)$ reflecting different links of contemporary turnover and transformation of the solar energy and atmospheric moisture [45]. These results was be used for paleogeographical and prognostic constructions in the light of global climate changes [46]. The taxonomic norms of hydrothermal parameters: their values average weighed by territory, - were calculated for each of the zonal-regional phytocoenological units which allowed the comparison of landscape-ecological parameters of the past, present and future.

Ideologically, prognostic analysis and mapping on the scale of the landscape-zonal ecosystems (region level) was based on the fundamental concept of global ecology [2, 22, $52,53]$ concerning the close relationship between natural zonality and the heat-to-moisture ratio. This ratio was characterized through the Vysotskii-Ivanov annual atmospheric humidity factor Fhum [44] - complex landscapegeophysical parameter which is best known in the Russian literature. It is ratio annual precipitation rann to the evaporativity E0 (potential evapotranspiration):

$$
\mathrm{F}_{\text {hum }}=\mathrm{r}_{\mathrm{ann}} / \mathrm{E}_{0}
$$

Parameters $\mathrm{E}_{0}$ and $\mathrm{F}_{\text {hum }}$ are formed mainly by average July temperature $\left(\mathrm{t}_{\mathrm{Jul}}\right)$, with high coefficient of determination $\left(\mathrm{R}^{2}\right)$ :

$$
\begin{gathered}
\mathrm{E} 0=1384-161,6 \text { tJul }+6,245 \text { tJul } 2 ; \mathrm{R} 2=0,87 ; \\
\text { Fhum }=12,09-0,9095 \text { tJul }+0, \\
01744 \text { tJul } 2 ; \mathrm{R} 2=0,88 .
\end{gathered}
$$

Connection of annual coefficient of humidification with average January temperature is non-significant. That means that during global warming the rise of winter temperature no will influence any significant on the landscape-zonal structure of the whole region Volga river basin. Main factor of future ecological reconstructions - changes of vegetation period temperature.

In contrast to rather schematic data on the global system of landscape-geophysical connections, as well as analogous scanty information on the Russian Plain, the stricter and more statistically substantiated regularities of the distribution of annual atmospheric humidity factor over natural zones (subzones) have been obtained for the territory of the Volga river basin, with two longitude-sector versions (Table 1). Extreme values of each $F_{\text {hum }}(1)$ interval fall on the southern and northern boundaries of the corresponding natural zone or subzone. Values of $F_{\text {hum }}(1)$ parameter for more southern boundaries of given region was next, according [54]: between north and middle steppe -0.60 ; between middle and south steppe - 0,50; between south steppe and semi-desert -0.32 .

Quite significant were the intrazonal longitude-sector changes in the warmth to humidity ratios determined by climate continentality. The greater continentality corresponded to the lower $F_{\text {hum }}(1)$ value, which conformed to the boundary conditions of a given natural zone (sub-zone). Even within the boundaries of the Russian Plain, one and the same zonal subdivision in the eastern, more continental sector is distinguished by higher aridity, and this longitudinal shift of relative humidity is comparable to the shift of zonal boundaries southwards for a whole subzone. 
Table 1. Comparison of zonal-regional atmospheric humidity factors for territory of Volga river basin with the same coefficients which reflect the natural zonality of Rusian Plain and the planetary system of zonality.

\begin{tabular}{llll}
\hline $\begin{array}{l}\text { Nature zones } \\
\text { (subzones) }\end{array}$ & $\begin{array}{l}\text { World system } \\
\text { of nature zones } \\
{[\mathbf{2 8}]}\end{array}$ & $\begin{array}{l}\text { Russian Plain } \\
{[\mathbf{5 4 ]}}\end{array}$ & $\begin{array}{l}\text { Volga river basin } \\
\text { and its encircle- } \\
\text { ment (West / East) }\end{array}$ \\
\hline Middle taiga & $1.87-2.00$ & $1.07-1.76$ & $\begin{array}{l}> \\
\text { > }\end{array}$ \\
& & 1.88 \\
South taiga & $1.33-1.69$ & $\begin{array}{l}1.63-1.88 \\
1.35-1.62\end{array}$ \\
& $1.52-1.61$ & & $1.22-1.63$ \\
Mixed forest & & $0.78-1.46$ & $1.00-1.35$ \\
& $1.20-1.24$ & & $1.09-1.22$ \\
Broadleaf forests & & $1.08-1.18$ & $0.97-1.00$ \\
Typical and south & $0.99-1.03$ & & $0.76-1.09$ \\
forest-steppe & & $0.67-0.98$ & $0.76-0.97$ \\
& $0.73-0.74$ & & $0.70-0.90$ \\
North steppe & & $0.51-0.80$ & $0.60-0.76$ \\
\hline
\end{tabular}

Footnote. For World systems data are showed for the boundaries between nature zones and subzones.

An analysis of the previous or future bioclimatic zonality of the region in comparison with its present-day zonality is usually performed with regard to primary vegetation, as its exogenous dynamics most adequately reflect climatic changes [55]. Regional operational units of vegetation were primary phytocoenological systems as the most sensitive to climatic changes, presented in the legend to "Plant map of the European part of the USSR and the Caucasus" [56]. According to [40], we refer these unities to classes (and subclasses) of plant formations, which are regional variants (e.g., East-European or Kama-Pechora) of vegetation types and subtypes (middle-taiga, sub-taiga, etc.). On the territory of the Volga River basin there are 17 groups of primary plant formations (Table 2).

Zonal-regional phytocoenological units show fairly strong dependence on annual coefficient of humidification (Table 3). The whole territory of the basin has about 170 meteostations, 120 agrometeorological stations, and more than 300 observation points. Climatic niches of vegetation form a single continued series by this factor, without any marked leaps and with continuously changing taxonomic norms of $F_{\text {hum }}$. Such series points to a sequence of anticipated phytocoenological transitions at this or that climatic trend. For example, at a $F_{\text {hum }}$ decrease from $1.85-1.65$ to $1.23-1.12$, the fir-woods of middle and south taiga of the upper Volga must transform into broad-leaved darkconiferous and/or pine formations, and then the latter - into the more continental dark-coniferous sub-taiga of the lower Kama river and into broadleaf and pine forests.

Table 2. Classification scheme of primary plant formation for headwater of the Volga river basin, and its encirclement, by [40,56].

\begin{tabular}{|c|c|c|c|c|}
\hline \multirow{2}{*}{$\begin{array}{l}\text { Zonal types } \\
\text { and classes }\end{array}$} & \multirow{2}{*}{ Regional variants } & \multirow{2}{*}{ Sub-zonal subtypes } & \multicolumn{2}{|l|}{ Groups of plant formations } \\
\hline & & & Brief characteristic & Symbol \\
\hline \multirow{6}{*}{$\begin{array}{l}\text { Dark conifer } \\
\text { and broad-leaf } \\
\text { - dark conifer } \\
\text { forests } \\
\text { (secondary as } \\
\text { birch) }\end{array}$} & \multirow{3}{*}{$\begin{array}{l}\text { East European } \\
\text { (Upper Volga region) }\end{array}$} & Middle taiga & Spruce green mosses with smollshrubs (1) & \\
\hline & & South taiga & Spruce smollshrub-grass (3) & 保 \\
\hline & & Sub-taiga & Broadleaf-spruce complex nemorose-herbal (5) & \\
\hline & \multirow{3}{*}{$\begin{array}{l}\text { Kama - Pechora } \\
\text { - West Ural region }\end{array}$} & $\begin{array}{l}\text { Middle } \\
\text { and south taiga }\end{array}$ & $\begin{array}{l}\text { Fir-spruce and spruce-fir grass-smollshrub, with green mosses, and } \\
\text { grass (2) }\end{array}$ & \\
\hline & & \multirow{2}{*}{ Sub-taiga } & Fir-spruce complex nemorose-herbal (6) & \\
\hline & & & Broadleaf-fir-spruce nemorose-herbal (7) & \\
\hline \multirow{3}{*}{$\begin{array}{l}\text { Pine and } \\
\text { bro-adleaf-pine } \\
\text { forests } \\
\text { (secondary } \\
\text { aspen-birch) }\end{array}$} & \multirow{3}{*}{$\begin{array}{l}\text { East European } \\
\text { (Upper Volga region) }\end{array}$} & $\begin{array}{l}\text { Middle } \\
\text { and south taiga }\end{array}$ & Pine, with spruce, green mosses with smoll-shrubs (4) & \\
\hline & & Sub-taiga & $\begin{array}{l}\text { Pine (with oak in undergrowth) smollshrub-grass (8) } \\
\text { Broadleaf-pine and pine complex, with spruce (9) }\end{array}$ & \\
\hline & & $\begin{array}{l}\text { Forest-steppe } \\
\text { and steppe }\end{array}$ & $\begin{array}{l}\text { Pine and broadleaf-pine, with steppe undergrowth, and herbs-cereals } \\
\text { (12) }\end{array}$ & S \\
\hline \multirow[t]{2}{*}{ Broadleaf forests } & \multirow[t]{2}{*}{ East European } & \multirow{2}{*}{$\begin{array}{l}\text { Northern } \\
\text { forest-steppe }\end{array}$} & Lime-oak and oak (10) & \\
\hline & & & Lime with admixture of other broadleaf kinds (11) & \\
\hline \multirow{3}{*}{$\begin{array}{l}\text { Typical and } \\
\text { Southern } \\
\text { forest-steppe }\end{array}$} & \multirow[b]{2}{*}{ of the Pontic type } & $\begin{array}{l}\text { Typical } \\
\text { forest-steppe }\end{array}$ & Meadow steppes with combination of oak forests (13) & $T_{111}$ \\
\hline & & $\begin{array}{l}\text { Southern } \\
\text { forest-steppe }\end{array}$ & Rich herb-sheep's fescue-feather grass steppes (14) & $\mathrm{k}$ \\
\hline & of the Transvolga type & $\begin{array}{l}\text { Southern } \\
\text { forest-steppe }\end{array}$ & Rich herb-sheep's fescue-feather grass steppes (15) & $\mathrm{W}$ \\
\hline \multirow[b]{2}{*}{ Steppes } & of the & Norhern steppe & Mixed herb-sheep's fescue-feather grass steppes (16) & س \\
\hline & $\begin{array}{l}\text { Trans-volga- } \\
\text { Kazakh-stan type }\end{array}$ & Southern(dry-) steppe & $\begin{array}{l}\text { Sheep's fescue-feather grass and wormwood steppes } \\
\text { (17) }\end{array}$ & מש \\
\hline
\end{tabular}

Statistical analysis revealed highly significant correlations between positions of zonal (sub-zonal) boundaries and standart values of $F_{\text {hum }}$. Values of $F_{\text {hum }}(1)$ were taken (with an interval of $25 \mathrm{~km}$ ) on the boundaries of natural zones and subzones and processed statistically. For west and east sectors of the Volga Region frontier quantities of 
coefficient of humidification are equal:

$\begin{array}{llll}1.88 & 1.63 & 1.22 & 1.09\end{array}$

Middle - South - Mixed - Broadleaf - Forest- taiga taiga forests forests steppe

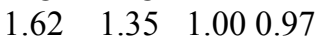

Table 3. Ecological optimas ( ) and second ("fuzzy") parts of climatic niches (X) for groups of plant formations at the space of the hurridity factor $F_{\text {loum }}$. Results of informational analysis was executed by the method [66]

\begin{tabular}{|c|c|c|c|c|c|c|c|c|c|c|c|c|c|c|c|c|}
\hline \multirow{3}{*}{$\begin{array}{l}\text { Graduations of } \\
\text { the humidity } \\
\text { factor }\end{array}$} & \multicolumn{16}{|c|}{ Groups of plant formations } \\
\hline & $\hat{\uparrow}$ & 㷊 & $\Psi$ & $\hat{\alpha}$ & 猞 & 本 & 茟 & $\Psi$ & 剑 & $\varphi$ & $Q_{Y}$ & 0 & $\Psi_{m}$ & v/ & $W$ & $=$ \\
\hline & 1 & 4 & 7 & 2 & 3 & 5 & 8 & 9 & 6 & 10 & 11 & 13 & 12 & 14 & 15 & 16.17 \\
\hline $0.50-0.61$ & & & & & & & & & & & & & & $x$ & $\mathbf{0}$ & $\boldsymbol{\theta}$ \\
\hline $0.61-0.73$ & & & & & & & & & & & & & $\mathrm{x}$ & $\bullet$ & $\bullet$ & $x$ \\
\hline $0.73-0.82$ & & & & & & & & & & & $x$ & $x$ & $\bullet$ & $\bullet$ & $x$ & \\
\hline $0.82-0.96$ & & & & & & & & & & $x$ & $\bullet$ & $\bullet$ & $x$ & $x$ & & \\
\hline $0.96-1.04$ & & & & & & & & $x$ & $\bullet$ & $x$ & $\bullet$ & $x$ & $x$ & & & \\
\hline $104-1.12$ & & & & & & & $x$ & $\bullet$ & $\bullet$ & $\bullet$ & $x$ & & & & & \\
\hline $1.2-1.23$ & & & & & & $\bullet$ & $\bullet$ & $x$ & $x$ & $x$ & & & & & & \\
\hline $1.23-1.33$ & & & $x$ & $\times$ & $x$ & $x$ & $\bullet$ & & & $x$ & & & & & & \\
\hline $133-1.45$ & & & $\bullet$ & $\bullet$ & $\bullet$ & & $x$ & & & & & & & & & \\
\hline $1.45-1.55$ & & $x$ & $x$ & $\bullet$ & $x$ & $x$ & & & & & & & & & & \\
\hline $155-1.65$ & $x$ & $x$ & $\bullet$ & $x$ & $x$ & & & & & & & & & & & \\
\hline $165-1.75$ & $x$ & $\bullet$ & $x$ & $x$ & & & & & & & & & & & & \\
\hline $1.75-1.85$ & $x$ & $\bullet$ & & & $\bullet$ & & & & & & & & & & & \\
\hline $185-2.00$ & - & $x$ & & & $x$ & & & & & & & & & & & \\
\hline $\begin{array}{l}\text { Standart of } \\
F_{\text {lum }}\end{array}$ & 180 & 1.73 & 1.47 & 1.42 & 154 & 123 & 1.21 & 1.12 & 107 & 107 & 094 & 090 & 0.80 & 0.72 & 0.62 & $\begin{array}{l}0.55 \\
0.40\end{array}$ \\
\hline
\end{tabular}

Variation Coefficient is $\leq 4-6 \%$, and only for the boundaries of forest-steppe zone it arrives $10-11 \%$. These correlations were used for the making a prognostic map of natural zones (subzones) in the region on the basis of the corresponding prognostic $\mathrm{F}_{\text {hum }}$ maps.

Summer moisture content in soil also correlates well with the coefficient of humidification, determining the latitude-zonal character of its distribution both at present and in the future. For agrophytocoenoses of the Volga river basin, the connection between the July resources of productive moisture $(\mathrm{mm})$ in a 1-m soil layer (W-100) and the parameter $\mathrm{F}_{\text {hum }}$ is as follows:

$$
(\mathrm{W}-100)=98.57 \cdot \mathrm{F}_{\text {hum }}-19.8 ; \mathrm{R}=0.86 ; \mathrm{R}_{2}=0.73
$$

Estimation of the past and future values of the annual surface and underground flow $\left(\mathrm{S}_{\mathrm{sur}}\right.$ and $\left.\mathrm{U}_{\mathrm{gw}}\right)$ needed additional water-balance calculations. For the optimum of Holocene and the predicted period of 2050, the surface flow was determined by the linear formula of its connections with the annual precipitation total and mean July temperature. The basis of calculations is that, according to the climatic prognoses, the anticipated changes in geophysical parameters will not go beyond the contemporary (for the last 100 years) climate variations, for which the data of instrumental observations are available. Therefore, these periods may be calculated using the contemporary connections expressed by an equation of multiple regression with the high coefficients of correlation R:

$$
\begin{aligned}
& \mathrm{S}_{\text {sur }}=0.1028 r_{\text {year }}-37.724 t_{\text {July }}+794 ; \mathrm{R}=0.90 \\
& \mathrm{U}_{\mathrm{gw}}=0.0776 \mathrm{r}_{\text {year }}+0.2079 \mathrm{~S}_{\text {sur }}-38 ; \mathrm{R}=0.87
\end{aligned}
$$

The situation for the dates of years 2100 and further will be quite different. The state of the atmosphere will proba- bly go beyond its variations in the historical past known by the factual data. New factors will appear, the main of them being the increase of atmospheric humidification along with the temperature growth, which almost was not observed previously [57]. The similar pattern evidently occurred in the optima of Mikulino interglacial period, when the climate was not only warmer but also much more humid than at present [58-60]. In these cases one may use a single-factor connection of surface runoff with atmospheric precipitation by exponential equation (though with the lower coefficient of correlation than in the first case -0.82 ):

$$
\mathrm{S}_{\mathrm{sur}}=\exp \left(2.402+0.004 r_{\text {year }}\right) ; \mathrm{R}=0.82
$$

Total annual evaporation is by $70 \%$ determined by the combined effect of annual precipitation and immediate runoff. Their partial influence, as well as the influence of the mean July temperature, proved to be unreliable. The annual underground flow is determined, according to [61], as $\mathrm{U}_{\mathrm{ann}}=\mathrm{W}_{\mathrm{gr}}-\mathrm{E}_{\mathrm{et}}$, where $\mathrm{W}_{\mathrm{gr}}=\mathrm{r}_{\text {year }}-\mathrm{S}_{\text {com }}$.

The summer stored soil productive moisture in layers 0 $20 \mathrm{sm}(\mathrm{W}-20), 0-50 \mathrm{sm}(\mathrm{W}-50)$ and $0-100 \mathrm{sm}$ are directly associated with the mean July temperature, but they may also be measured by $E_{0}$ and $S_{\text {sur }}$ :

$$
\begin{gathered}
(\mathrm{W}-20)=0.0257 \cdot \mathrm{r}_{\text {year }}+0.0676 \cdot \mathrm{S}_{\text {sur }}-0.0136 \cdot \mathrm{E}_{0}+0.8 ; \\
\mathrm{R}=0.88 ; \\
(\mathrm{W}-50)=0.0631 \cdot \mathrm{r}_{\text {year }}+0.1746 \cdot \mathrm{S}_{\text {sur }}-0.0231 \cdot \mathrm{E}_{0}+7.6 ; \\
\mathrm{R}=0.89 ; \\
(\mathrm{W}-100)=0.0964 \cdot \mathrm{r}_{\text {year }}+0.3216 \cdot \mathrm{S}_{\text {sur }}-0.0802 \cdot \mathrm{E}_{0}+33.5 ; \\
\mathrm{R}=0.86 .
\end{gathered}
$$

Thus, the shifts in the state of hydroedaphotops must be 
determined by not only precipitation increase or decrease, but also the changes in the water balance expenditure (runoff and evapotranspiration) which, in their turn, are determined by the thermal conditions of the warm period.

The adduced formulas for calculation of soil moisture content belong only to open territories of agroecosystems. The transition to the same parameters for forest-covered lots may be realized with the help of empirical equalities [46].

In essence, a landscape-ecological prognosis for the nearest several decades is functional rather than structural. Characteristic times of metabolic parameters are much smaller than those of morphological parameters of ecosystems [42]. Changes in the rates of organic matter reproduction and decomposition occur within the period ranging from a few months to three to five years [33, 44, 55], which is commensurate to the time of general shift in the climatic system itself. Thus, the object of functional prognosis is the minor biological cycle. The functional relaxation of the ecosystem should entail its subsequent structural changes.

The minor biological cycle is considered with regard to two discrete parameters: net primary production (Pprim) and the coefficient of annual above-ground phytomass destruction CY, also known as the litter-fall index [62], which is determined as a mass ratio of forest litter (in herbaceous ecosystems, dead plants) to the annual increment of green phytomass in all above-ground vegetation layers. Taken together, Pprim and CY characterize the concordant "functioning" of both bioproduction and detrital segments of the minor biological cycle.

Regional empirical relations of bioproductivity of natural ecosystems with two geophysical parameters: annual radiation balance $R_{\mathrm{ann}}$ and Budyko's radiation index of drought (aridity) $I_{\text {dry }}$, have been determined (Fig. 2). Parametr $I_{\mathrm{dry}}$ is calculated by formula [21]:

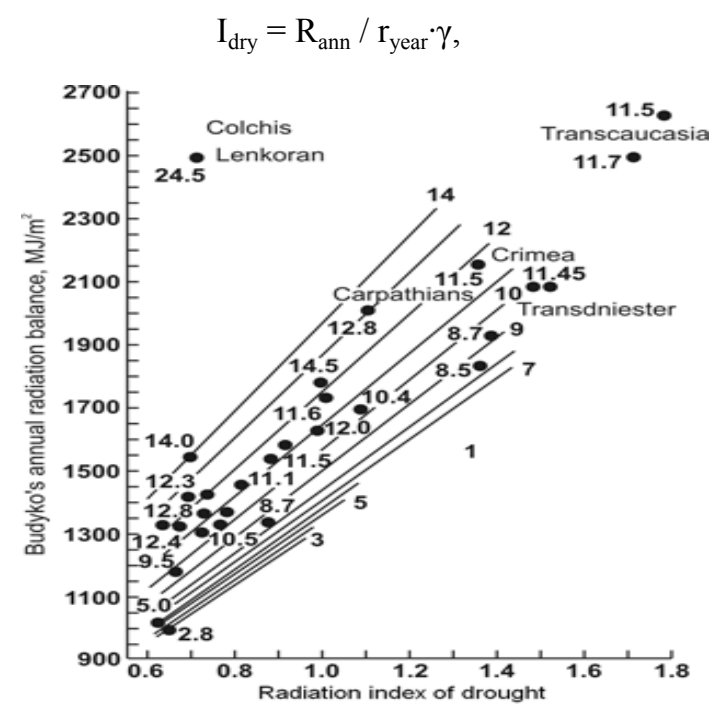

Fig. 2. Distribution of primary productivity of natural ecosystems $(t / h \cdot y e a r-1)$ in coordinate field of annual radiate balance and radiate index of the drought for territory of Russian plain and its encirclement. where $\gamma$ is latent heat of vapor formation. In his turn parameter $R_{\mathrm{ann}}$ was determined as

$$
\mathrm{R}_{\mathrm{ann}}=0.378 .8 \cdot \mathrm{t}_{\text {july }}-6.667 \cdot \mathrm{t}_{\text {July }}{ }^{2}-3180 ; \mathrm{R}^{2}=0.92 \text {. }
$$

The nomogram of relations is based on selected regions of the Russian Plain and adjacent plain and mountain territories that, first, have the known factual values of productivity of different zonal-regional plant formations from northern taiga to forest-steppe and northern steppes [63, 64] and, second, have the available data on radiation balance and atmospheric precipitation. The nomogram used more than 80 points with factual values of the primary bioproductivity of landscapes, annual radiation balance, and annual precipitation total. To obtain the more leveled picture of bioproductivity, particular values of the latter in the field of $R_{\text {ann }}$ and $I_{\text {arid }}$ were associated into pleiads (groups), and the mean value of productivity was calculated for each of them. Thereby we managed to obtain a family of straight lines in the range of 3-14 ton/ha that characterized an unambiguous dependence of productivity on specified geophysical parameters for each pleiad.
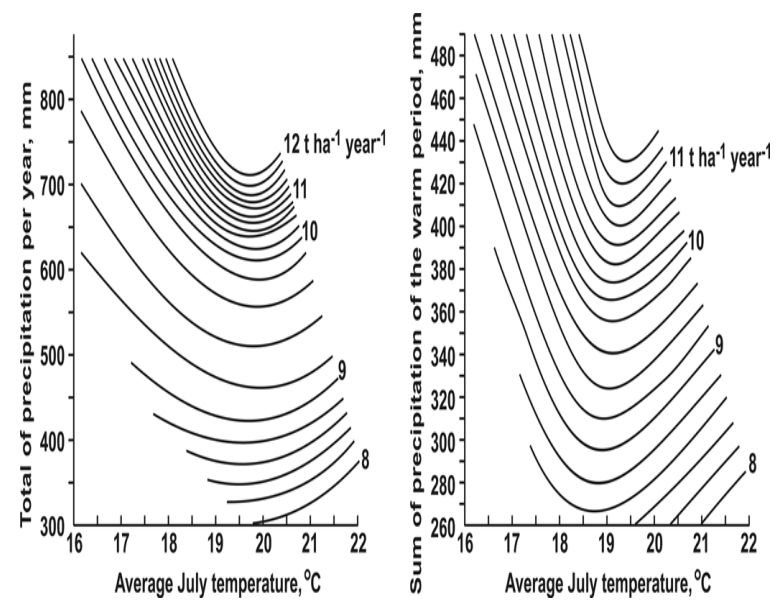

Fig. 3. Dependent of primary bioproductivity from average July temperature and sum of precipitation - per year (a) and of the warm period (b).Primary bioproductivity may by also calculated by the initial hydroclimatic characteristics: temperature and precipitations, - which appear as itself climatic prognosis (Fig. 3). Each nomogram has been created on the base of climatic standards by 120 meteostation of Volga river basin and of empirical data for primary bioproductivity. The of $C Y$ values were taken from the map published in the study by [62].

\subsection{Information Models of Plant Formation Climatic Niches}

On the preliminary stage of predictive analysis, the two main parameters of space landscape-ecological connections were used [65, 66]: (1) normalized coefficient of interrelation $\mathrm{C}(\mathrm{X} ; \mathrm{Y})$ of phenomenon $\mathrm{X}$ with factor $\mathrm{Y}$ (in each pair of characters) and (2) partial coefficient of connection $\mathrm{C}\left(\mathrm{x}_{\mathrm{i}}\right.$ $/ y_{j}$ ) as a means of "disclosure of information code" determining the degree of spatial connection of separate gradations (states) of phenomenon $\left(\mathrm{x}_{\mathrm{i}}\right)$ and factor $\left(\mathrm{y}_{\mathrm{i}}\right)$. The probabilities of either landscape-zonal or biogeocoenose transition for the given prognostic data were estimated using the bank of hydrothermal niches. For this purpose, the meas- 
ures of inclusion for contemporary and forecasted partial climatic niches of the landscape-zonal kinds or biogeocoenosis groups were calculated. Each niche is represented in the form a row vector - "fuzzy" set of probability (meeting) ecosystem states $\mathrm{X}\left(\mathrm{x}_{1}, \mathrm{x}_{2}, \ldots, \mathrm{x}_{\mathrm{i}}, \ldots, \mathrm{x}_{\mathrm{n}}\right)$ in the space of states of the given factor $Y\left(y_{1}, y_{2}, \ldots, y_{j}, \ldots, y_{m}\right)$. The row vector consists of normalized partial association coefficients [65]:

$$
\mathrm{C}\left(\mathrm{x}_{i} / \mathrm{y}_{j}\right)=\mathrm{p}\left(\mathrm{x}_{i} / \mathrm{x}_{i}\right) / \mathrm{P}\left(\mathrm{x}_{i}\right),
$$

where $\mathrm{P}\left(\mathrm{x}_{\mathrm{i}}\right)$ and $\mathrm{p}\left(\mathrm{x}_{\mathrm{i}} / \mathrm{y}_{\mathrm{j}}\right)$ are a priori and conditional probability, respectively. It is agreed that the association between $\mathrm{x}_{\mathrm{i}}$ and $\mathrm{y}_{\mathrm{i}}$ is significant at $\mathrm{C}\left(\mathrm{x}_{\mathrm{i}} / \mathrm{y}_{\mathrm{j}}\right)>1$.

The matrix of partial association coefficients describes a system of hydro-thermal (ecological) niches of any multitude of ecosystems, defined as "zones of consumption", in the space of changes of the given geophysical parameter, i.e. as a certain combination of vital factors of the environment [42]. In this aspect, the conception of niche is applicable not only to individual species of plants or animals but also to entire biotic communities, ecosystems, and their selected structure-function attributes [53, 67]. The fundamental basis of this conception is unchanged. As concerns the plant formations at hand (see below), the essence of such generalization is as follows: for each of them, not all of the component plant species are studied but mainly the populations that form phytocoenological systems and are apparent from the denomination of plant formations.

It is accepted that each value $\mathrm{C}\left(\mathrm{x}_{\mathrm{i}} / \mathrm{y}_{\mathrm{j}}\right)$ is a certain equivalent of probability of the zonal-regional biogeocoenosis group $\mathrm{i}$ by the given graduation $\mathrm{j}$ of a geophysical parameter. The coefficient is higher at a high-level probability, therefore the components of row vector $\mathrm{C}\left(\mathrm{x}_{\mathrm{i}} / \mathrm{y}_{\mathrm{j}}\right)$ are considered as "weighting" coefficients. Such matrices were used to obtain taxonomic base norms of the above hydrothermal parameters: the values average weighed by the territory (see Table 1). The central values of all gradations for given geophysical parameter and matrixes of normalized (by the columns) partial association coefficient have been used for calculation of taxonomic norms.

If define the ecological domination in each vectorcolumn of a niche by symbol "•" and "fuzzy" links of the niche by symbol " $x$ ", then we will obtain a formalized matrix of climatic niche. In this form, the matrix clearly demonstrates the character and closeness of connections (see Table 1). The most probable (dominant) value of ecological niche at the given gradation of the phenomenon is taken as stable, corresponding to the equilibrium process of changes in the phenomenon state by the gradient of factor conditions. The series of ecological niches by each phenomenon describe a phase space of the system of factorphenomenon [67].

The phase space of ecological niches reflects the dynamics of their volume under changing factor states. While moving along the lines of the matrix or along the line of ecological determinants (which is the same), one can follow the variation of "homeostasis reserve" of the pheno- menon and, accordingly, its sensitivity to the changes in factor states. Abrupt narrowing or broadening of the niche demonstrates that with each subsequent state the phenomenon changes the character of its response to the variation of factor states, becoming more or, on the contrary, less sensitive to this factor. It appears that irreversible changes occur in the mechanisms of interaction between the components of phenomenon system and its behavior becomes nonlinear, according to [68]. The nonlinear character of transition of the states of phytocoenotic, soil, and landscape complexes as a whole by the arid gradient is typical of their binary relations with the most of abiotic factors under consideration. It adds complicating uncertainty to the landscapeecological prediction based on the principle of actuality [69].

\section{Methodology of Landscape- Ecological Prognoses and Paleore- constructions}

\subsection{Prefatory Remarks}

Strategy of the landscape-ecological prognosis may be put into next algorithm: first to carry out an identification of picked out ecosystem objects (zonal and sub-zonal phytocoenological systems) to certain values of contemporary climatic conditions, and then to make an estimate of the most probable transformation of revealed ecological (hydrothermal) niches of given objects according of expected climatic changes for given prognostic date. For all that, it is suggested a plural of the transformation of ecosystems at a fixed value of the hydro-thermal trend when a new state can share a number of trains of not one but several states which are known at present instants of time.

The general principle of the prognosis is expressed in the following: value of the climatic-caused transformation of one ecosystem into another is the greater, the lesser is the degree of intersection of their climatic niches in the initial states, that is, the greater are the contemporary contrasts of their functional states, and the larger will be the range of the overlap of niches after the rapprochement of ecosystems by the given climatic factor. By the maximum values of transformation the most probable directions and the conversion degree of the ecosystem are estimated. At the same time, an unambiguous character of transformation of regional ecosystems is proposed at a fixed value of geophysical trend, when the new state may have features of not one but several states existing at a given moment.

\subsection{Evaluate of Probabilities of Changes in the Func- tional States of Ecosystems}

The mechanism of estimation of probability of ecosystem transitions (for the predictions) or deviations (for the paleoreconstructions) is illustrated by Venn's diagram (Fig. 4). Here, $A_{0}$ and $A_{1}$ are respectively an initial (contemporary) and final (future) values of the row vector of the eco- 
logical niche of object A (either landscape kind or facies group), which must be absorbed by another object B if its niches intersect each other in the final state more than in the initial state. The landscape-ecological transition proceeds in the direction $\mathrm{A} \rightarrow \mathrm{B}$, and the absorption proceed in the opposite direction $\mathrm{B} \rightarrow \mathrm{A}$. The shaded area $\mathrm{a}+$ $\mathrm{b}+\mathrm{c}$ on the diagrams reflects the total value of transformation of object A, which can be expressed in terms of the following measure of inclusion by [70]:

$$
\mathrm{a}+\mathrm{B}=\mathrm{A}_{0} \cap \mathrm{A}_{1} ; \mathrm{B}=\mathrm{A}_{0} \cap \mathrm{B}_{0} ; \mathrm{B}+\mathrm{c}=\mathrm{A}_{1} \cap \mathrm{B}_{0},
$$

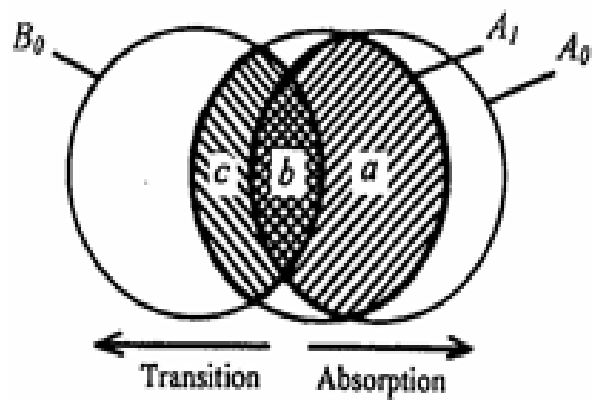

Fig. 4. Venn's diagram, illustrating the mechanism of probability estimation of landscape-ecological transitions (explanation in the text).

where " $\cap$ " is the sign of intersection (logical product) of two sets. The elements of the intersection "zone" belong to two sets simultaneously.

It is supposed that any object A must be absorbed by another object $\mathrm{B}$ if its niches intersect each other in the final state more than in the initial state. Initial (contemporary) $A_{0}$ and final (future) values $A_{1}$ of the row vector of the climatic niche of object $A$ are considered. In each researched pair of objects A and B, two parameters of transformation are calculated: the probability measure $\mathrm{P}_{\mathrm{ii}}$ of object A stabilization: $\mathrm{K}\left(\mathrm{A}_{0} \rightarrow \mathrm{A}_{1}\right)$; and the measure $\mathrm{P}_{\mathrm{ij}}$ of its absorption by object $\mathrm{B}: \mathrm{K}\left(\mathrm{A}_{0} \rightarrow \mathrm{B}_{0}\right)$. These parameters are expressed in the following measures of inclusion [44]:

$$
\begin{aligned}
& K\left(A_{0} \rightarrow A_{1}\right)=\frac{A_{0} \cap A_{1}}{A_{0}} ; \\
& K\left(A_{0} \rightarrow B_{0}\right)=\frac{A_{1} \cap B_{0}-A_{0} \cap B_{0}}{A_{0}} .
\end{aligned}
$$

Since the operations are performed with descriptive fuzzy sets, the operating formulas have the next shape:

$$
\begin{gathered}
K\left(A_{0} \rightarrow A_{1}\right)=\frac{\sum_{1}^{N P} \min \left[L_{i}\left(A_{0}\right), L_{j}\left(A_{1}\right)\right]}{\sum_{1}^{N} L_{i}\left(A_{0}\right)} ; \\
K\left(A_{0} \rightarrow B_{0}\right)=\frac{\sum_{1}^{P Q} \min \left[L_{j}\left(A_{1}\right), L_{k}\left(B_{0}\right)\right]-\sum_{1}^{N Q} \min \left[L_{i}\left(A_{0}\right), L_{k}\left(B_{0}\right)\right]}{\sum_{1}^{N} L_{i}\left(A_{0}\right)} .
\end{gathered}
$$

Hear $\mathrm{i}, \mathrm{j}$ and $\mathrm{k}$ - order numbers of partial association coefficients in row vectors describing the ecological niches accordingly $\mathrm{A}_{0}, \mathrm{~A}_{1}$ and $\mathrm{B}_{0}$.
By analogy, we calculate the values of transitions $\mathrm{K}\left(\mathrm{A}_{0} \rightarrow \mathrm{C}_{0}\right), \mathrm{K}\left(\mathrm{A}_{0} \rightarrow \mathrm{D}_{0}\right)$, etc. For the following state, we have $\mathrm{K}\left(\mathrm{B}_{0} \rightarrow \mathrm{B}_{1}\right), \mathrm{K}\left(\mathrm{B}_{0} \rightarrow \mathrm{C}_{0}\right), \mathrm{K}\left(\mathrm{B}_{0} \rightarrow \mathrm{D}_{0}\right)$, etc. For the next stage of prediction, its own measures of transition are calculated: $\quad \mathrm{K}\left(\mathrm{A}_{0} \rightarrow \mathrm{A}_{2}\right), \quad \mathrm{K}\left(\mathrm{A}_{0} \rightarrow \mathrm{B}_{0}\right), \quad \mathrm{K}\left(\mathrm{A}_{0} \rightarrow \mathrm{D}_{0}\right), \quad \ldots$; $\mathrm{K}\left(\mathrm{B}_{0} \rightarrow \mathrm{B}_{2}\right), \mathrm{K}\left(\mathrm{B}_{0} \rightarrow \mathrm{C}_{0}\right), \mathrm{K}\left(\mathrm{B}_{0} \rightarrow \mathrm{D}_{0}\right), \ldots$

The formulas for calculations at this stage have a general view of:

$$
\begin{aligned}
& K\left(A_{0} \rightarrow A_{2}\right)=\frac{A_{0} \cap A_{2}}{A_{0}} \\
& K\left(A_{0} \rightarrow B_{0}\right)=\frac{A_{2} \cap B_{0}-A_{0} \cap B_{0}}{A_{0}} .
\end{aligned}
$$

Thus, a specific quadratic matrix of probabilities of stabilization of each object (diagonal elements of the matrix, $\left.\mathrm{P}_{\mathrm{ii}}\right)$ and its transitions into other objects $\left(\mathrm{P}_{\mathrm{ij}}\right)$ is obtained for each prediction period. Here, the zero and negative values of probabilities are possible. The former indicate the absence of transitions and the latter show intensification of the contrast between the functional states of objects (at $\mathrm{A}_{1} \cap \mathrm{B}_{0}<\mathrm{A}_{0} \cap \mathrm{B}_{0}$ ). Further operations are executed with the transition probability matrices. All negative transitions are provisionally replaced by zeros.

If objects $A$ and $B$ are first-order neighbors, then the value of displacement of the boundary between them in the A $\rightarrow \mathrm{B}$ direction is taken as proportional to the calculated measure of transformation of object A. In its turn, object B can be transformed into the following objects (D, C, etc.). The evolution of ecosystems is usually multivariate; hence, all possible transitions have to be considered for each of them with revealing the maximum measures of transformation, which will indicate the most probable directions of transformation of phytocoenological structures as a whole. For first-order landscape neighborhoods, this process will be rather distinct if $\mathrm{P}_{c n}(\mathrm{~B})>\mathrm{P}_{\mathrm{cn}}(\mathrm{A})$, i.e., given that absorbing object $\mathrm{B}$ has a higher power of climatic niche $\mathrm{P}_{\mathrm{cn}}$ compared to absorbed object A.

\subsection{Algorithm of Predictive Calculations}

The procedure of the stage of own prognosis analysis consisted of the following operations [44].

1. Using the information analysis of connections on each object (plant formation) with that or other climatic characteristic two matrices of partial association coefficients $\left(\mathrm{C}\left(\mathrm{x}_{\mathrm{i}} / \mathrm{y}_{\mathrm{j}}\right)\right)$ were obtained: matrix $\mathrm{T}_{0}$ for the base period and matrix $T_{1}$ for the given prognostic dates. On the columns of each matrix the graduations of the given factor are placed, and on the lines the gradations given object are. Because the regional climatic prognosis is differentiated with respect to temperature and precipitation, so we have formed 4 pairs of matrixes: on average January and July temperature $\left(\mathrm{T}_{0}(1)\right.$ and $\mathrm{T}_{1}(1) ; \mathrm{T}_{0}(2)$ and $\mathrm{T}_{1}(2)$ and on the quantity of atmospheric precipitation of cold and warm periods $\left(\mathrm{T}_{0}(3)\right.$ and $\mathrm{T}_{1}(3) ; \mathrm{T}_{0}(4)$ and $\mathrm{T}_{1}(4)$. Paleoreconstruction is created usually by annual sum of precipitation, therefore 
three matrices are initial in this case.

2. The formulae above serve to calculation of four square matrixes $\mathrm{T}(1), \mathrm{T}(2), \mathrm{T}(3)$ and $\mathrm{T}(4)$ of measures of stabilization (resistant stability) Pii of each i-th object (diagonal matrix elements) and measures of its transformation $P_{i j}$ into other $j$-th objects. Zero values of matrix elements show the absence of a transition in the given pair of objects, and negative values point to the intensification of contrast between them $\left(\mathrm{A}_{1} \cap \mathrm{B}_{0}<\mathrm{A}_{0} \cap \mathrm{B}_{0}\right)$.

For simplification of predictive calculations, the above condition $\mathrm{P}_{\mathrm{cn}}(\mathrm{B})>\mathrm{P}_{\mathrm{cn}}(\mathrm{A})$ is not taken into consideration at the given stage of described algorithm development, which certainly reduces the reliability of results.

3. Account was to be taken of simultaneous changes of all four (or three) cited climatic factors, then, on a basis of matrices $\mathrm{T}(1)-\mathrm{T}(4)$ the first factor-weighted average matrix $\mathrm{T}_{\mathrm{wa}}$ of object transformation was calculated. The "weighting" coefficients for its calculation were values of parameter $\mathrm{C}(\mathrm{X} ; \mathrm{Y})$ which were normalized once again to obtain, by [66], a linear polynomial of dependencies between the distributions of objects and the geophysic factors under consideration. For the groups of plant formations prognostic calculations matrix $\mathrm{T}_{\mathrm{wa}}(1)$ were counted on the linear polynomial with the following coefficients:

$$
\mathrm{T}_{\mathrm{wa}}(1)=0.131 \cdot \mathrm{T}(1)+0.388 \cdot \mathrm{T}(2)+0.147 \cdot \mathrm{T}(3)+
$$$$
0.334 \cdot \mathrm{T}(4) \text {. }
$$

For paleoreconstructions matrix $\mathrm{T}_{\mathrm{wa}}(1)$ was created by next linear polynomial:

$$
\mathrm{T}_{\mathrm{wa}}(1)=0.161 \cdot \mathrm{T}(1)+0.477 \cdot \mathrm{T}(2)+0.362 \cdot \mathrm{T}(3) .
$$

4. At this stage of operations with the matrices it is necessary to take into account the probable presence of "residual" transitions of some or other object into other prototype objects absent in our operational system (sampling), i.e., to extra-sampling objects. For some facial groups, these transitions seem to be dominant and even unique. Such transitional "residue" $\mathrm{P}_{\mathrm{ij}}(\mathrm{x})$ for each object (i.e., for each line of the weight-average transition matrix) can be easily found from the ratio:

$$
\mathrm{P}_{i j}(\mathrm{x})=1-\mathrm{P}_{i i}-\sum \mathrm{P}_{\mathrm{ij}} .
$$

The $\mathrm{P}_{\mathrm{ij}}(\mathrm{x})$ values are entered as an additional column into matrix $\mathrm{T}_{\mathrm{wa}}$. If the "residue" is negative, it means that all predicted transitions of the given object are in the limits of the considered set of prototype objects and there are no other transitions. Negative "residues" of transitions are changed for zeros.

5. Comparable values of the probabilities of transition of some or other object into different prototype objects can be obtained if the sum of these probabilities in each line of the matrix is equal to 1 . After normalizing each of the five $T_{w a}$ matrices (with "residual" columns) by lines, we will obtain the second weight-average matrices $\mathrm{T}_{\mathrm{wa}}(2)$. The lines of the matrix with positive transition "residues" prove to be normalized already at the preceding $\left(4^{\text {th }}\right)$ stage of calculations.
6. In conclusion, the correcting procedure is performed. Matrix $\mathrm{T}_{\text {wa }}(2)$ contains quite a lot of elements with very low (below 1-2\%) probabilities going beyond the limits of measurement and calculation accuracy. It is necessary to calculate the guaranteed minimum of probabilities of landscape-ecological transitions: $\mathrm{M}_{\min }$. The most simply method of finding the guaranteed minimum of elements is based on application of one-sided criterion of their significance, $t=\sigma$, which provides the $5 \%$ level of significance [71]. All values of $\mathrm{M}$ transitions or deviations $\left(\mathrm{P}_{\mathrm{ii}}\right.$ or $\left.\mathrm{P}_{\mathrm{ij}}\right)$ below the difference of $M-\sigma$ must be eliminated. With this purpose, we calculate $\mathrm{M}_{\min }=\mathrm{M}-\sigma$ and drop all vector elements below this difference.

Thus, each object acquires much shorter transition vector. Residual vector elements are normalized again and, thus, we obtain the third matrix of transition probabilities weighted by the given geophysical factor: the $\bar{T}_{\text {wa }}(3)$ matrix. It gives a rather clear notion of the potentials of transformation of some or other objects or, on the contrary, their ability to resist external influence. The orientate graphs of probabilities of functional transitions between the objects are plotted on the basis of $\mathrm{T}_{\mathrm{wa}}(3)$ matrices (see below Fig. 6). These graph-analytical models are the main tool for landscape-ecological prediction. They give the most general notion of the exogenous succession dynamics of ecosystems as whole natural-territorial complexes.

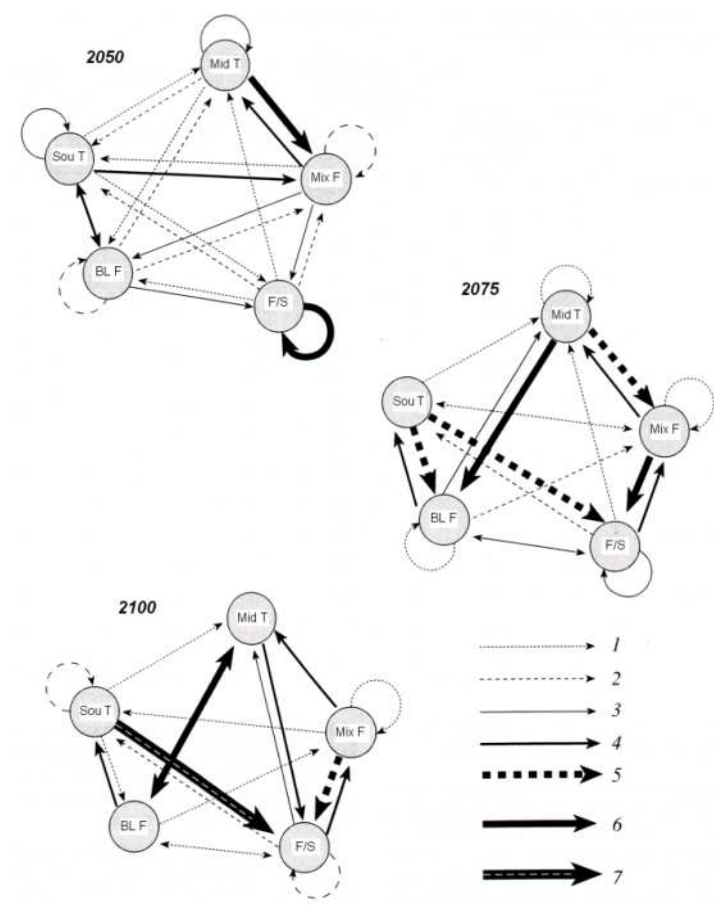

Fig. 6. Directions and probabilities of functional transformation of the landscape-zonal systems on the territory of the Volga river basin and its surrounding for different prognostic dates, according to GISS model. Landscape-zonal systems: Mid T-middle taiga; Sou T-southern taiga; Mix F-mixed forest; $B L F$ - broadleafforest; $F / S$ - typical and southern forest-steppe. Probabilities of landscape-zonal transitions: $1-0.10$ and less ; $2-0.11-0.20 ; 3-0.21-0.30 ; 4-0.31-0.40 ; 5-0.41-0.50 ; 6-$ $0.51-0.60 ; 7-0.81-0.90$. 


\section{Prognoses and Paleogeographical Reconstructions of Landscape-Zonal Conditions}

\section{1. Representation of Calculating Climatic Model and Paleoclimate Reconstruction}

All of the known developments of global and regional ecological predictions are based on deviations of the main climatic system parameters anticipated in the nearest century from their values in a certain base period under the effect of anthropogenic changes in chemical composition of the atmosphere, with some or other consideration of the role of social and economic factors of civilization development $[1,4,21,72$, etc.). As a base period, we have taken the 100-year interval (1881-1980) of instrumental observations of the hydro-meteorological network with the results published as multiyear climate norms. This interval covers the entire so-called industrial period. During this period, the European territory of Russia passed through the five largest climatic cycles, each about 15 years [73]. The upper limit of fluctuations of 11-year moving averages, which fell on approximately 1985, was taken as the beginning of prognostic period characterizing the modern global warming. Starting with this time, the annual temperature progressively increased during the $80-90$ s of the 20th century, leaving the previous extreme points of the base period far behind.

We will consider two main prognostic intervals (steps): 1985-2050 and 2050-2100. Considerable part of first predictive step (1985-2050) is already passed at present The following values of the main climatic parameters for the end of each interval will be used as ecological estimates: the mean January and July temperatures, annual precipitation, and precipitation of the cold and warm periods. The 10 -year average values of these parameters are taken for each term, including 5 years before and after this date. The averaging by decades is extensively used during the analysis of multiyear climatic fluctuations and reveals rather significant connections of the regional spectra of temperature courses with the change of atmospheric circulation forms [74], which provides the correctness of such averaging when using the climate prediction models of general atmospheric circulation.

The hydrothermal trends for the period up to 2100 have been taken from global coupled atmosphere ocean general circulation model (AOGCMs) GISS - Goddard Institute of Space Search, USA [75-77]. This model predicts the relatively temperate global warming. It is one of the most preferable general circulation models, according to the results of testing of statistical significance of the data obtained and simulation of the state of contemporary climate, including its seasonal characteristics [78]. It has been successfully used in a number of prognostic-ecological researches [48, 72, 79, etc.]. Initial global model GISS-1988 has been transformed for regional level (territory of Russian Plain) in model GISS-1993 by G.V. Menzhulin and S.P Savvateev according to our request. Transformed model GISS-93 has turned out to be more realistic as compared with the initial model GISS-88 [45].

Primary GISS climatic scenario had been based on the supposition that the doubling of concentration $\mathrm{CO} 2$ in atmosphere as compared with "preindustrial period" (18861905) will be reach to year 2050 [57]. More late investigations published in 2003 and $2006[80,81]$ make to move away this date to the end of 21 st century. Proceed from that we will move the dates of GISS scenarios by next manner: $2010 \rightarrow 2050,2050 \rightarrow 2100$ (see Tables 4-6, 8). Further steps have been calculated with the help of extrapolation.

Spatial resolution of the GISS model with an interval of $1^{\circ}$ latitude and $1^{\circ}$ longitude allowed the computer mapping (software package "Arc View GIS, Vers. 3.0") of the main hydroclimatic parameters: temperature, precipitation, evaporation, annual atmospheric humidify factor, etc, on the working scale of $1: 2,500,000$, i.e., much larger than it had been done previously in ecological prognoses and paleoreconstructions.

The calculations of hydrothermal conditions of the above epochs of the geological past (optima Mikulino interglacial and optima Holocene) were based on the materials of point paleoclimatic reconstructions (by separate profiles) for the territory of the Russian Plain, according to $[58,59]$. Unfortunately, the network of base points proved to be insufficient for standard mapping on the given scale. The way out was found as follows. First, basing on the idea of a single character of plant cover evolution in the Volga river basin in Holocene [82], one might assume the territorial integrity of bioclimatic conditions of the region at all stages of development of its contemporary zonal structure. Second, following the developments [58], we have accepted that the total character of main hydrothermal fields of the region in the geological epochs under consideration was analogous to the modern one. Consequently, the pattern of relative differences between some or other regions was similar. This allowed a nonlinear extrapolation to map sites with lacking factual data, using the maps of hydrothermal parameters for the base period as analogies.

The regional landscape-ecological prognosis and paleogeographical reconstructions developed by the author is distinguished by a qualitatively new level of spatial resolution as compared with the available analogous maps to the Russian Plain [8, 12, 19, 83]. Accordingly, it is managed to carry out a much deeper scenario interpretation of prognostic and paleogeographical models. Besides, the use of annual atmospheric humidify factor but not only values of temperature or precipitation, as is usually done, gave a more objective assessment of future landscape-ecological conditions of the region on the basis of retrospective prognosis.

It should be noted that, in case paleogeographical maps reflect the location of landscape-zonal systems actually occurring in the past (in this sense, such models are equilibrium), the prognostic mapping assesses only few equifinal states, to which these systems will tend in the course of 
first functional (metabolic) and then structural transformations under the action of climatic signals. Prognostic models are non-equilibrium, and zonal areas presented on them, as well as probabilities of transitions, indicate the landscape-zonal conditions, in which these ecosystems will function in the nearest decades. The matter concerns first of all the changes in the rate of small biological turnover and transition of an ecosystem to a new level of balance of the productive and detritus branches of metabolism. This process is quite adequate by duration to the total shift of landscape-ecological conditions. Thus, the object of priority in landscape-ecological prognosis is functional relaxation as a primary reaction of ecosystems to external impact. In ecological assessments of anticipated global warming for the nearest decades, the matter may concern only functional but not structure-morphological prognosis.

\subsection{Main Features of Climatic Prognosis in the Region}

According to the GISS model, the temperature rise expected in the next few decades in the temperate belt of the Russian Plain will be more prominent in the warm rather than cold season (see Table 2). By the year 2050, the average July temperature will generally increase by $1.1-1.3{ }^{\circ} \mathrm{C}$ and, in some areas of the sub-taiga and broadleaf forest subzones, even by $1.5-1.7^{\circ}$.

The duration of vegetation period will be increased everywhere as well. The average January temperature, by contrast, will become only $0.2-0.5^{\circ}$ higher. It is of great ecological significance because, as we have already shown before [44], the structural changes in vegetation and soils are determined mostly by their functional shifts just in the period of vegetation. Initial prognosis has already been partially justified: in 1995-1999, which turned out to be the warmest of instrumentally monitored periods, the deviation of mean annual temperature from the 20-year norm of "pre-industrial period" (1886-1905) on the European territory of Russia was $0.7-0.8^{\circ}$ to $1.9^{\circ}$ [73].

The rate of warming after 2050 will remain generally the same, with the monthly average temperatures exceeding the corresponding baseline values by $2.2-2.3^{\circ}$. However by the year 2050, the rise of the average January temperature will finally become prevalent, reaching $4.5-5.0^{\circ}$. Thus, considerable shifts in the thermal energy supply to ecosystems will take place in all natural zones of the Volga basin, with the ecological effect of these shifts increasing in a north-south direction. Taiga and nemoral forests will remain under climatic conditions of the temperate belt. Formations of the southern forest steppe and, especially, the northern steppe will pass from the sub-boreal to the subtropical thermal-radiation category according to classification [28]; i.e., they will be in a different climatic belt. The anthropogenic warming will be accompanied by a general increase in precipitation. By 2050 and 2100, the annual amounts of precipitation in the middle and southern taiga subzone will increase by $100-120$ and $200-270 \mathrm{~mm}$, and those in the forest-steppe with broadleaf forests and in the northern steppe will increase by $60-80$ and $100-150 \mathrm{~mm}$, respectively. More abundant precipitation in the worm season will account for $70-80 \%$ of this increase. Natural climate fluctuations may periodically intensify or weaken the predicted process of total aridization of natural ecosystems in the Volga river basin caused by anthropogenic enhancement of the atmospheric greenhouse effect. However, yet it seems impossible to quantitatively assess this correction at each stage of prediction. One can only give the following estimates and considerations. The amplitude of supercentury and century fluctuations of the global and regional mean annual air temperature reached $1-2^{\circ}$ in the past. Consequently, in future it may be considered as commensurable to anthropogenic warming only till the beginning of the $30 \mathrm{~s}$ of the $21^{\text {st }}$ century.

We have analyzed the materials on climatic changes that occurred during the recent 30-year period (1975-2004) in the Middle Belt of European Russia [10]. The analysis showed a generally satisfactory adequacy of the climate prediction of GISS model being used at the initial stage of global warming. During that period, the mean July temperature rose by $2.7^{\circ}$ on average in the Upper Volga Region and by $2.2-2.5^{\circ}$ in the Middle Povolzhye (Middle Volga Region). As we can see, the actual thermal shift even advances the predicted one: it would have set in only in 2030-2040 according to the GISS model (see Table 4).

As regards the conditions of atmospheric humidification, the recent climatic trend was also fully corresponded to the GISS prediction. By 2004 the sum of biologically active temperatures in the Povolzhye region had increased by 30 $100^{\circ}$, with almost unvaried annual precipitation; therefore, the Vysotzky-Ivanov's atmospheric humidify factor decreased by $0.07-0.10$. It means that the hydrothermal regime of broadleaf forests shifted to the southern boundary of their areal, approaching the conditions of typical forest steppe (trend $\mathrm{F}_{\text {hum }}=1.37 \rightarrow 1.30$ ), while mixed forests of the southern belt of sub taiga zone turned out to be in the state of neighboring nemoral-forest communities (trend $\mathrm{F}_{\text {hum }}=1.29 \rightarrow 1.19$ ).

Comparison of both GISS scenarios (1988 and 1993) by a number of landscape-geophysical parameters with the scenarios of another models of the AOGCMs family [4]: GFDL and UKMO models, - shows that they generally predict unambiguous, though expressed in varying degrees, lowering of atmospheric humidify factor by 2050 in the wide range of natural zones of the Russian Plain: from south taiga to middle steppe. It undoubtedly indicates the dominance of thermo-arid climatic trend. At the same time, as compared to GFDL and particularly UKMO models, GISS-93 gives quite moderate climate aridization, especially in the forest and forest-steppe zones of the Russian Plain.

It is also necessary to take into account significant seasonal differences in the natural climate fluctuations. In the period of 1965-1990, the increasing positive temperature trend was noted for the latitudes of the Middle band of the Russian Plain for January (reaching $1.0-1.2^{\circ}$ ) while the smoothed curve of the mean July temperature had zero deviations. Generally, the change of epochs of natural cool- 
ing and warming relative to the summer season is rather weakly manifested in temperate latitudes; deviations from the norm are no more than $\pm 0.2-0.6^{\circ}$ [59]. Due to this reason, one can hardly consider as essential the correction introduced by the natural climate fluctuations into the ecological effect determined by the increasing atomospheric greenhouse effect. Considering the changes in the mean January temperature and winter precipitation, the ecological role of which is comparatively low $[28,84]$, as the most significant changes, one may suppose that reduction of this effect will be no more than $25-30 \%$ of predicted value.

Table 4. Taxonomical standards of average January and July temperatures for zonal types/sub-types and groups of plant formations on the Volga river basin and forecasted changes of these parameters, according to GISS model.

\begin{tabular}{|c|c|c|c|c|c|c|c|}
\hline \multirow{3}{*}{$\begin{array}{l}\text { Zonal types and } \\
\text { subtypes of plant } \\
\text { formations }\end{array}$} & \multirow{3}{*}{$\begin{array}{l}\text { Groups of for- } \\
\text { mations }\end{array}$} & \multicolumn{3}{|c|}{ Average January temperature } & \multicolumn{3}{|c|}{ Average July temperature } \\
\hline & & \multirow[b]{2}{*}{$\begin{array}{l}\text { Base } \\
\text { period }\end{array}$} & \multicolumn{2}{|c|}{ Deviation } & \multirow{2}{*}{$\begin{array}{l}\text {-Base } \\
\text { period }\end{array}$} & \multicolumn{2}{|c|}{ Deviation } \\
\hline & & & $\begin{array}{l}2050 \\
(2010)\end{array}$ & $\begin{array}{l}2100 \\
(2050) \\
\end{array}$ & & $\begin{array}{l}2050 \\
(2010) \\
\end{array}$ & $\begin{array}{l}2100 \\
(2050) \\
\end{array}$ \\
\hline \multirow{4}{*}{ Middle and south taiga } & $x_{1}$ & -12.2 & 0.6 & 3.7 & 16 & 1.3 & 3.2 \\
\hline & 2 & -15.6 & 1.4 & 5 & 16.7 & 1.1 & 3 \\
\hline & 和3 & -11.6 & 0.5 & 4 & 17.2 & 0.8 & 2.7 \\
\hline & 14 & -11.9 & 0.6 & 3.9 & 17.4 & 0.7 & 2.7 \\
\hline \multirow{5}{*}{ Subtaiga } & X 5 & -10.2 & 0.2 & 3.3 & 17.3 & 0.7 & 3 \\
\hline & 求 6 & -14.7 & 0.9 & 4.8 & 18 & 0.8 & 2.6 \\
\hline & 車 7 & -13.9 & 0.5 & 4.5 & 18.6 & 0.8 & 2.6 \\
\hline & 198 & -12.2 & 0.5 & 4.1 & 18.8 & 1.1 & 2.8 \\
\hline & 199 & -12 & 0.3 & 3.8 & 19.2 & 1.1 & 2.8 \\
\hline \multirow{2}{*}{$\begin{array}{l}\text { Broadleaf } \\
\text { forests }\end{array}$} & $\Gamma_{10}$ & -11 & 0.1 & 3.7 & 18.7 & 1 & 3 \\
\hline & ' 11 & -11.5 & -0.2 & 3.3 & 19.6 & 1.1 & 3 \\
\hline \multirow{2}{*}{$\begin{array}{l}\text { Typical } \\
\text { forest-steppe }\end{array}$} & $T_{\text {III }} 12$ & -12.5 & 0.3 & 4.3 & 20.2 & 1 & 3 \\
\hline & $\varphi_{111} 13$ & -11.1 & 0.1 & 3.5 & 20.5 & 1.3 & 3.3 \\
\hline \multirow{2}{*}{$\begin{array}{l}\text { South } \\
\text { forest-steppe }\end{array}$} & $W_{14}$ & -12.3 & 0.4 & 3.9 & 21.6 & 0.9 & 3 \\
\hline & W 15 & -14.9 & 0.9 & 4.6 & 20.9 & 0.9 & 2.7 \\
\hline North steppe & ш 16 & -14.3 & 0.4 & 24.4 & 22.2 & 0.8 & 2.9 \\
\hline
\end{tabular}

Footnote. Conventional meanings of plant formation groups see in Table 2.

\subsection{Prognosis Evaluates of State of Regional Bioclimatic System}

Although the rise of summer and winter temperature will be accompanied by a certain increase in precipitation, particularly during the warm season, however the increment of precipitation will be insignificant and it will not be able to neutralize the temperature increase. Therefore the annual and summer humidity factors will start to decrease almost everywhere and quite significantly (see Table 5). Besides, the progressive summer aridization of soil will begin: the common event for the moderate belt of continents [4].

A simple calculation has shown: in order to slow down the aridization of the climate in boreal forests $\left(\Delta F_{\text {hum }}=0\right)$ at a $1.5-2.5^{\circ}$ increase of the mean July temperature, which will be observed nearly everywhere in 2075, the annual precipitation total must increase for $210-220 \mathrm{~mm}$, and the temperature growth for $3.5-4.5^{\circ}$ in 2050 must be neutralized by precipitation increment of $240-250 \mathrm{~mm}$. Pluvial compensation relative to the same temperature increase must be as higher as the soil layer is thicker. According to HadCM3, the mean July temperatures in the Middle Volga region will have increased by 2100 for more than $7-8^{\circ}$, and neutralization of such increase will call for the minimal increment of annual precipitation of about $1000 \mathrm{~mm}$.

Such situation is not predicted for this region by any of the AOGCM models (see [21, 80]). It is not observed in paleoclimatic analogs either. For example, the annual precipitation in Mikulino interglacial period exceeded the modern norm for no more than $100 \mathrm{~mm}$ [58]. Even for Pliocene as an analog of climatic conditions of the second half of the $21^{\text {st }}$ century, the annual precipitation increment in the Middle belt of the Russian Plain is below $200 \mathrm{~mm}$ [85].

Thus, up to the end of the $21^{\text {st }}$ century, the thermo-arid climatic trend will develop on the territory of the Volga river basin and its surroundings (Figs. 5 and 6). This is evidenced by the negative values of changes in the atmospheric humidity factor dominating at all stages of the forecast period (see Table 5), as well as July reserves of productive moisture in soil (see Table 8). The anticipated global anthropogenic warming will cause general aridization of the regional bioclimatic system, and this aridization will become still deeper and more total with time. The most significant aridization is expected for the first decades of the $21^{\text {st }}$ century, when the increment of atmospheric precipitation will be yet especially low compared to temperature increase. 
Table 5. Taxonomical standards of totals of precipitation per year and atmospheric humidity factor on the Volga river basin and forecasted changes of these parameters, according to GISS model.

\begin{tabular}{|c|c|c|c|c|c|c|c|}
\hline \multirow{3}{*}{$\begin{array}{l}\text { Zonal types and } \\
\text { subtypes of plant } \\
\text { formations }\end{array}$} & \multirow{3}{*}{$\begin{array}{l}\text { Groups } \\
\text { of for- } \\
\text { mations }\end{array}$} & \multicolumn{3}{|c|}{$\begin{array}{l}\text { Totals of precipitation } \\
\text { per year, } \mathrm{mm}\end{array}$} & \multicolumn{3}{|c|}{$\begin{array}{l}\text { Atmospheric humidity } \\
\text { factor }\end{array}$} \\
\hline & & \multirow{2}{*}{$\begin{array}{l}\text { Base } \\
\text { period }\end{array}$} & \multicolumn{2}{|c|}{ Deviation } & \multirow{2}{*}{$\begin{array}{l}\text { Base } \\
\text { period }\end{array}$} & \multicolumn{2}{|c|}{ Deviation } \\
\hline & & & $\begin{array}{l}2050 \\
(2010) \\
\end{array}$ & $\begin{array}{l}2100 \\
(2050) \\
\end{array}$ & & $\begin{array}{l}2050 \\
(2010)\end{array}$ & $\begin{array}{l}2100 \\
(2050) \\
\end{array}$ \\
\hline \multirow{4}{*}{ Middle and south taiga } & T1 & 768 & 14 & 172 & 1.80 & -0.14 & -0.24 \\
\hline & 1. 2 & 697 & 122 & 250 & 1.42 & -0.16 & 0.07 \\
\hline & A 3 & 759 & 94 & 229 & 1.73 & -0.13 & -0.21 \\
\hline & 4 & 737 & 59 & 193 & 1.47 & -0.02 & -0.08 \\
\hline \multirow{5}{*}{ Subtaiga } & $\mathrm{AP} 5$ & 763 & 62 & 196 & 1.54 & -0.01 & -0.18 \\
\hline & 和 6 & 679 & 54 & 170 & 1.23 & 0.06 & -0.03 \\
\hline & $\mathrm{M}_{7}$ & 630 & 44 & 158 & 1.07 & 0.04 & -0.04 \\
\hline & 198 & 650 & 56 & 148 & 1.21 & -0.09 & -0.13 \\
\hline & Y† & 652 & 50 & 178 & 1.12 & -0.02 & -0.15 \\
\hline \multirow{2}{*}{$\begin{array}{l}\text { Broadleaf } \\
\text { forests }\end{array}$} & $T_{10}$ & 655 & 64 & 156 & 1.07 & -0.10 & -0.19 \\
\hline & 'T' 11 & 602 & 56 & 134 & 0.94 & -0.02 & -0.10 \\
\hline \multirow{2}{*}{$\begin{array}{l}\text { Typical } \\
\text { forest- } \\
\text { steppe }\end{array}$} & $Y_{111} 12$ & 556 & 81 & 121 & 0.80 & 0.05 & -0.08 \\
\hline & $\Psi_{111} 13$ & 536 & 109 & 158 & 0.90 & -0.06 & -0.27 \\
\hline \multirow{2}{*}{$\begin{array}{l}\text { South } \\
\text { forest-steppe }\end{array}$} & $\mathrm{V} / \mathrm{1} 14$ & 507 & 77 & 126 & 0.72 & -0.02 & -0.26 \\
\hline & $\mathbb{W}_{15}$ & 509 & 48 & 81 & 0.62 & 0.06 & -0.03 \\
\hline North steppe & III 16 & 438 & 66 & 81 & 0.57 & -0.11 & -0.26 \\
\hline
\end{tabular}

Footnote. Conventional meanings of plant formation groups see in Table 2.

By 2050, the thermo-arid trend had to manifest itself not so strongly, causing different starting rates of relaxation of plant formations. Their common function-structure reorganization had to be apparently begin in the extreme north of the basin (see Figs. 5 and 6), where the hydrothermal signal is the strongest. Here, $F_{\text {hum }}$ had to decrease for $0.1-$ 0.2 almost in all middle and south taiga landscapes, and July reserves of soil moisture made decrease for $20-30 \%$. The conditions for transgression from the south of mixedforest formations followed by oak forests made be formed, as it happened, e.g., in the xerothermal epoch of Holocene. Sub-taiga pine forests and lime-oak forests turn out to be in an unstable condition as well. They made start to be swallowed up by motley-grass and cereal pine forests of typical forest-steppe, the transgression of which is determined by the presence here in this period of thermo-humid trend. Finally, a significant initial decrease of atmospheric humidification $\left(\Delta \mathrm{F}_{\text {hum }}=-0.11\right)$ had to occur in the extreme southeast, in the northern steppe of Samara Zavolzhye (Trans-Volga region). Under the conditions of contemporary high deficit of moisture, such a trend of warmth to moisture ratio made have to exert a noticeable effect of further aridization and desertification of this semiarid territory.

At the period 2050-2075, the annual humidify factor will decrease greatly as a whole almost everywhere. The outlined picture of transforming tendencies in the taiga zone will persist. However, a weakly expressed thermohumid trend $\left(\Delta \mathrm{F}_{\text {hum }}=0.07-0.08\right)$ will appear in the eastern sector of the basin, and south-taiga formations will start to evolve to their western, less continental analogs, with a slowdown of the total aridization process. Quite an intensive manifestation of thermo-arid trend in the Upper-Volga south taiga $\left(\Delta \mathrm{F}_{\text {hum }}=-0.34\right)$ will cause definite weakening of longitude-sector bioclimatic contrasts in the whole taiga zone.

Aridization will also spread to the subzones of typical and southern forest-steppe. Motley-grass and cereal oak forests (here, the $\mathrm{F}_{\text {hum }}$ decrease will be 0.38 ) will be most unstable and suffer an intensive expansion of continental formations of the southern forest-steppe of Samara's TransVolga region. The latter will spread also to the west, into their analogs of the near-Black Sea types. Finally, The process of desertification of Trans-Volga/Kazakhstan steppe will significantly intensify (see below Figs. 7 and 8).

At the next stage of the forecast period (2075-2100), the intensity of described processes will somewhat decline due to stabilization or even some decrease of the $\Delta \mathrm{F}_{\text {hum }}$ values. The greatest slowdown will be observed in the middle belt of the basin: in mixed forests of the eastern sector and in steppe pine and oak forests. At the same time, the processes of thermo-arid transformation will be intensive as before in the western sector, mainly in the middle taiga fir forests, mixed and broad-leaved forests, and in oak and southern 
forest-steppe. Thus, if anthropogenic thermo-arid trend in the first decades must appear mainly on the territory of the most continental eastern sector of the basin, after the middle of the prognostic period its effect will have shifted mostly to the western, the least continental sector.

In general, the result of these rearrangements will be as follows. Firstly, the most active development will be characteristic of two zonal vegetation types: mixed forests, on the one hand, and typical and southern forest-steppes, on the other hand (see Figs. 2-8). By the mid-21st century, almost the entire Volga basin will be in the sub-boreal belt, and, hence, the forest-steppe will become dominant, absorbing other types of plant formations. Secondly, the nemoral forest subzone will sharply narrow and change its location, moving beyond the well-known oroclimatic barrier represented by a latitudinal segment of the Oka-VolgaKama river valley system. Its present-day territory will be fully covered by typical forest-steppe formations, which will also expand to the sub-taiga zone of the By-Ural Region. Oak-linden communities themselves will transgress the boundaries of the southern and even middle taiga subzones, producing new, mixed phytocoenotic structures and

thereby broadening the total area of the sub-taiga zone. Thirdly, bioclimatic contrasts will be sharply enhanced in the southeast of the region, which will entail the convergence of zonal and sub-zonal boundaries and even the appearance of the semidesert sub-zone at the latitude of Orenburg.

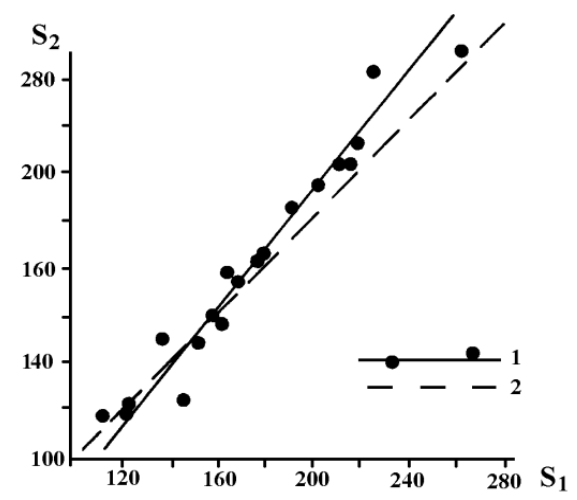

Fig. 7. Correlation of values of annual complete flow $(\mathrm{mm})$ for the observation periods before $1980\left(S_{1}\right)$ and before $1990\left(S_{2}\right)$ on the territory of headwater of Volga river basin. 1 - actually linear correlation; 2 - hypothetical straight line for condition what $S_{1}=S_{2}$.

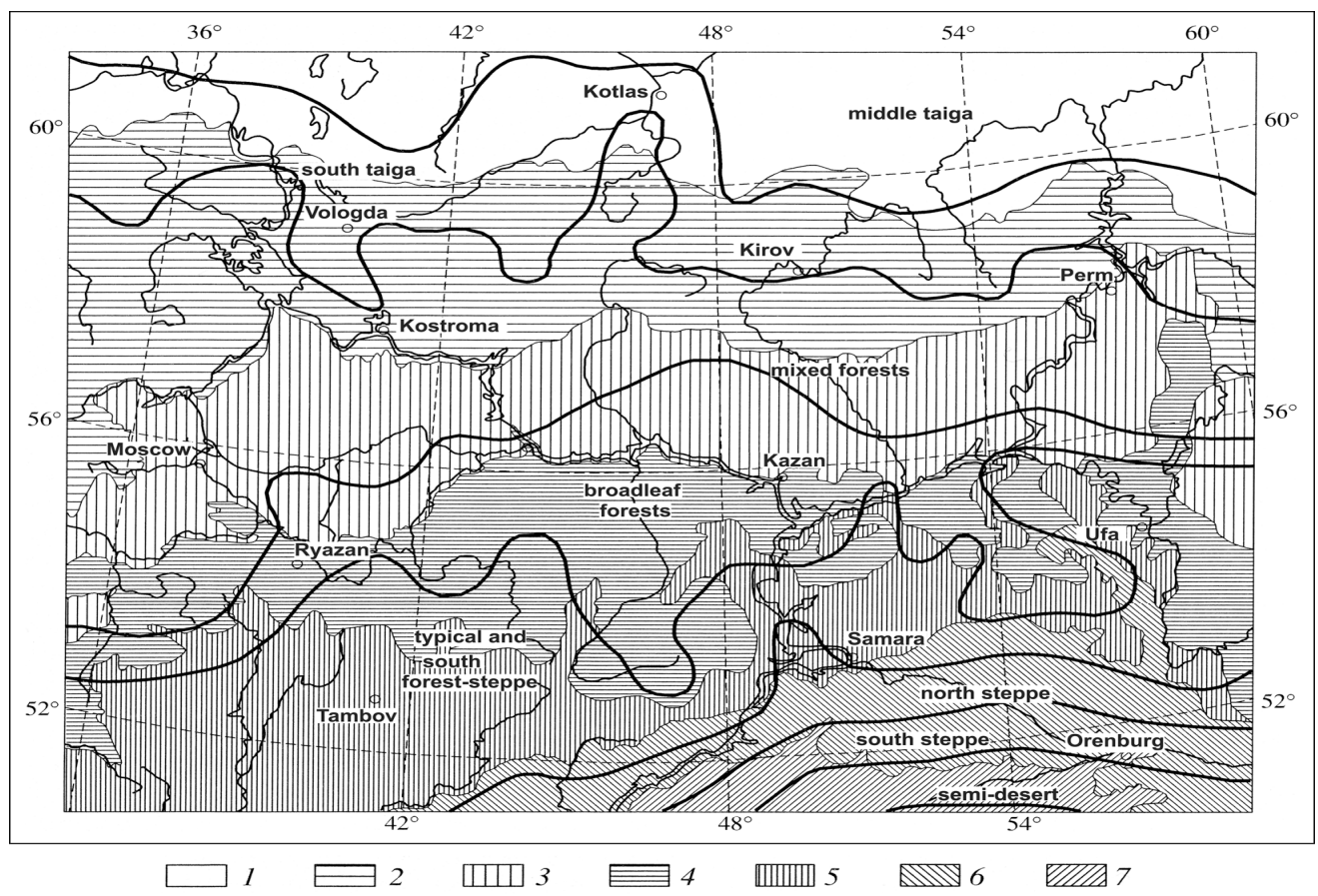

Fig. 8. Prognosis of changes in the landscape-zonal structure of the Volga river basin and its surrounding for the period to year 2030-2050, according to GISS model.Basic areals of natural zones and sub-zones: $a$ - middle taiga; $b$ - southern taiga; $c$ - mixed forest; $d$ - broadleaf forest; - typical and southern forest-steppe; $g$ - southern (dry) steppe. Boundaries of future natural zone/sub-zone (with their corresponding names) are showed by the isolines. Showed on the map the names of natural zone/subzone belong to the predictive date.

The above landscape-ecological prognosis is in good agreement with global scenarios of natural zonality that are based on different models, including the GISS model, and envisage a twofold increase in the atmospheric $\mathrm{CO}_{2}$ concentration $[4,7]$, i.e., the situation expected in 2100 . The maps made by the authors of these scenarios show that forest--steppe and steppe formations will deeply penetrate the forest zone of Eurasia. In European Russia, they will probably expand mainly over the Central Russian and Volga uplands. A prognosis made for the territory of the former Soviet Union [8] is fairly similar to the results obtained with our model.

\subsection{Changes in The Water Balance and Moisture Con- tent In Soil}

On the basis of predicted dynamics of temperature and 
precipitation, probable changes in components of the expenditure part of the water balance and July resources of productive moisture in soil have been assessed (Tables 6 and 7). The greatest increase in the water balance is suggested for surface runoff ( $25-40 \%$ to $70-85 \%$ in 2100 ) (see Table 7). This will be accounted for by the rise of precipita- tion amount $(22 \%)$ as well as by the relative reduction of the share of the groundwater flow in the water balance of the territory (from $28 \%$ by the year 1990 to $19 \%$ by the year 2100) by its common absolute increase of $15-20 \%$ in all nature zones except for north steppe and forest-steppe.

Table 6. Taxonomical standards of totals of annual surface and groundwater flow on the Volga river basin and forecasted changes of these parameters, according to GISS model.

\begin{tabular}{|c|c|c|c|c|c|c|c|}
\hline \multirow{3}{*}{$\begin{array}{l}\text { Zonal types and subtypes } \\
\text { of plant formations }\end{array}$} & \multirow{3}{*}{$\begin{array}{l}\text { Groups } \\
\text { of for- } \\
\text { mations }\end{array}$} & \multicolumn{3}{|c|}{ Annual surface flow, mm } & \multicolumn{3}{|c|}{ Annual groundwater flow, mm } \\
\hline & & \multirow{2}{*}{$\begin{array}{l}\text { Base } \\
\text { period }\end{array}$} & \multicolumn{2}{|c|}{ Deviation } & \multirow{2}{*}{$\begin{array}{l}\text { Base } \\
\text { period }\end{array}$} & \multicolumn{2}{|c|}{ Deviation } \\
\hline & & & $\begin{array}{l}2050 \\
(2010) \\
\end{array}$ & $\begin{array}{l}2100 \\
(2050) \\
\end{array}$ & & $\begin{array}{l}2050 \\
(2010) \\
\end{array}$ & $\begin{array}{l}2100 \\
(2050) \\
\end{array}$ \\
\hline \multirow{4}{*}{ Middle and south taiga } & $7_{1}$ & 213 & 19 & 79 & 53 & 5 & 20 \\
\hline & M2 & 203 & 23 & 80 & 57 & 7 & 23 \\
\hline & A 3 & 187 & 26 & 122 & 59 & 18 & 39 \\
\hline & $T_{4}$ & 148 & 36 & 89 & 66 & 17 & 40 \\
\hline \multirow{5}{*}{ Subtaiga } & M 5 & 148 & 67 & 126 & 37 & 17 & 32 \\
\hline & 求 6 & 157 & 28 & 91 & 42 & 7 & 24 \\
\hline & X7 7 & 123 & 29 & 73 & 41 & 9 & 25 \\
\hline & \% 8 & 100 & 38 & 77 & 35 & 14 & 27 \\
\hline & $\Psi \Psi_{9}$ & 109 & 17 & 51 & 29 & 5 & 13 \\
\hline \multirow{2}{*}{$\begin{array}{l}\text { Broadleaf } \\
\text { forests }\end{array}$} & $\mathrm{T}_{10}$ & 64 & 18 & 36 & 34 & 12 & 20 \\
\hline & U 11 & 104 & 16 & 45 & 49 & 12 & 21 \\
\hline \multirow{2}{*}{ Typical forest-steppe } & $Y_{\text {III }} 12$ & 82 & 26 & 41 & 30 & 10 & 16 \\
\hline & $\Psi_{111} 13$ & 64 & 38 & 33 & 19 & 11 & 10 \\
\hline \multirow{2}{*}{ South forest-steppe } & W/ 14 & 51 & 29 & 26 & 23 & 13 & 12 \\
\hline & W 15 & 50 & 23 & 32 & 21 & 9 & 13 \\
\hline North steppe & 世 16 & 31 & 21 & 27 & 17 & 11 & 14 \\
\hline
\end{tabular}

Footnote. Conventional meanings of plant formation groups see in Table 2.

Table 7. Volume increase of water balance components of Volga river basin for prognostic year 2100 (in \% by 1990), according to GISS model.

\begin{tabular}{lllll}
\hline $\begin{array}{l}\text { Nature zone } \\
\text { (sub-zone) }\end{array}$ & $\begin{array}{l}\text { Precipi- } \\
\text { tation }\end{array}$ & $\begin{array}{l}\text { Evapo- } \\
\text { ration }\end{array}$ & $\begin{array}{l}\text { Surface } \\
\text { river } \\
\text { flow }\end{array}$ & $\begin{array}{l}\text { Ground- } \\
\text { water } \\
\text { flow }\end{array}$ \\
\hline $\begin{array}{l}\text { Middle taiga } \\
\text { South taiga }\end{array}$ & 20 & 10 & 55 & 17 \\
Mixed forest & 28 & 4 & 70 & 13 \\
$\begin{array}{l}\text { Broadleaf } \\
\text { forest }\end{array}$ & 25 & 12 & 69 & 23 \\
Forest-steppe & 30 & 19 & 42 & 76 \\
North steppe & 25 & 6 & 35 & 0 \\
Whole region & 4 & 18 & 61 & 15 \\
\hline
\end{tabular}

Even at present it markedly increases in the Volga catchment basin. The comparison of runoff layer values calculated for the period of observations up to 1980 and 1990 , separately, shows that these values increased for $7 \%$ on the average, at the extension of a series of observations for 10 years (Fig. 7). The maximal growth of runoff layer will occur in the western sector of south taiga and mixed forests, the medium growth - in the subzone of broad-leaved forests, and the minimal growth - in southern forest-steppe and northern steppe. Numerical experiments with global models also give the increase of the flow in the continental regions lying north of the 50th parallel [21].

The groundwater flow and total evaporation will increase to a much lesser extent. According GISS model, in 2050, 2075 and 2100, their values (as compared with 1990) over the region on the average will increase as $5 \rightarrow 9 \rightarrow 15 \%$ and $4 \rightarrow 6 \rightarrow 11 \%$, respectively, and the surface runoff in forest-steppe and northern steppe actually will not increase. At the same time, the ratio of subsurface to surface runoff for the whole period will decrease from 0.28 to 0.19 on the 
average. In broadleaf forests and north steppe the total evaporation will equally increase (on the average, by 19\%), what will correlate with the increase by $13 \%$ of common humidification of these territories. At the sacrifice of the rise of precipitation amount the common humidification will increase in the zones of mixed forests and foreststeppe.

Thus, there will occur not a simple and unambiguous shift of all water balance components towards the increase, but reorganization of the very structure of the balance, i.e., of the ratio of its expenditure components - runoff and evaporation. This reorganization will consist in a disproportionately great increase of the share of surface river runoff due to a relative decrease of evaporation and subsurface flow. At the same time, the total expenditure of atmospheric moisture for the surface and subsurface runoff will increase much more than the expenditure for evaporation, which will cause general increase of runoff coefficient.
Such a change in the water balance structure will indicate a decrease in the extent of closure of the water cycle, which in turn, according to [5], should be considered as a significant cause of the decrease in tolerance of ecosystems for outer influence and as factor of the weakening of their resistance to external, including anthropogenic, impacts.

Over the whole territory of the basin, quite a significant decrease of soil moisture reserves in the middle of vegetation period is also predicted (see Table 8 ). It will be determined by the forestalling increase of summer temperatures as compared with the increase of precipitation of the warm season, which will reduce the atmospheric humidify factor. Significant decrease of productive soil moisture resource in the middle of vegetation period will be caused by quite a number of reasons: reduction of fore-spring snow resource, the earlier disappearance of snow cover and, finally, which is most important, increased evapotranspiration at a falling $\mathrm{F}_{\text {hum }}(1)$ (see Table 5).

Table 8. Taxonomical standards of summer soil moisture content and annual primary productivity of nature ecosystems $\left(P_{\text {prim }}\right)$ on the Volga river basin and their forecasted changes, according to GISS model.

\begin{tabular}{|c|c|c|c|c|c|c|c|}
\hline \multirow{3}{*}{$\begin{array}{l}\text { Zonal types and sub- } \\
\text { types of plant } \\
\text { formations }\end{array}$} & \multirow{3}{*}{$\begin{array}{l}\text { Groups of for- } \\
\text { mations }\end{array}$} & \multicolumn{3}{|c|}{$\begin{array}{l}\text { July stored soil moisture } \\
\text { in layer } 1 \mathrm{~m}, \mathbf{m m}\end{array}$} & \multicolumn{3}{|c|}{ Annual primary productivity, $\mathbf{t} / \mathbf{h}$} \\
\hline & & \multirow{2}{*}{$\begin{array}{l}\text { Base } \\
\text { period }\end{array}$} & \multicolumn{2}{|c|}{ Deviation } & \multirow{2}{*}{$\begin{array}{l}\text {-Base } \\
\text { period }\end{array}$} & \multicolumn{2}{|c|}{ Deviation } \\
\hline & & & $\begin{array}{l}2050 \\
(2010) \\
\end{array}$ & $\begin{array}{l}2100 \\
(2050) \\
\end{array}$ & & $\begin{array}{l}2050 \\
(2010) \\
\end{array}$ & $\begin{array}{l}2100 \\
(2050) \\
\end{array}$ \\
\hline \multirow{4}{*}{ Middle and south taiga } & 1 & 181 & -39 & -125 & 9.7 & 2.9 & 5.7 \\
\hline & 耗2 & 134 & -14 & -65 & 11 & 1.9 & 4.9 \\
\hline & 倞 3 & 167 & -52 & -105 & 11.5 & 1.8 & 5.1 \\
\hline & & 130 & -23 & -70 & 11.4 & 1.6 & 4.6 \\
\hline \multirow{5}{*}{ Subtaiga } & X 5 & 129 & -14 & 73 & 11.8 & 1.3 & 4 \\
\hline & th 6 & 121 & -31 & 70 & 10.2 & 2 & 4.4 \\
\hline & A 7 & 103 & -32 & 60 & 9 & 2.4 & 4.6 \\
\hline & 198 & 95 & -31 & -88 & 11 & 1 & 3 \\
\hline & 149 & 78 & -22 & -46 & 11 & 1.6 & 3.1 \\
\hline \multirow{2}{*}{$\begin{array}{l}\text { Broadleaf } \\
\text { forests }\end{array}$} & 10 & 103 & -34 & -67 & 11.2 & 0.8 & 3.2 \\
\hline & 'T'11 & 71 & -21 & -45 & 9.5 & 2 & 3.6 \\
\hline \multirow{2}{*}{$\begin{array}{l}\text { Typical } \\
\text { forest-steppe }\end{array}$} & $T_{111} 12$ & 64 & -21 & -44 & 9.7 & 1.3 & 3 \\
\hline & $\varphi_{111} 13$ & 62 & -25 & -44 & 9.5 & 1.6 & 3 \\
\hline \multirow{2}{*}{ South forest-steppe } & $\sqrt{1} 14$ & 46 & -19 & -32 & 8.1 & 1.7 & 3.2 \\
\hline & 15 & 38 & -4 & -20 & 8.3 & 0.7 & 1.8 \\
\hline North steppe & 世 16 & 28 & -5 & -18 & 7.1 & -1.3 & 1.1 \\
\hline
\end{tabular}

Foot-note. Conventional meanings of plant formation groups see in Table 2.

So, in Podmoskovye (the near-Moscow territory) already in 2050 the level of moisture content in soil is expected to fall for $17 \%$, which will bring it nearer to the minimum in the spectrum of modern fluctuations of humidity $(22 \%$ from the average for the period of observations 1965-1984 (see [86]). In 2075, the decrease in the many-year norm of moisture reserves will be 1.5 -fold less than this minimum, and in 20 more years the decrease will be 2.5 -fold. Thus, already at the second prognostic stage, the many-year reserves of productive moisture in soil will go beyond the lower level of their contemporary year-to-year variability.

By the middle of the $21^{\text {st }}$ century, the July moisture reserves in a 1-m soil layer of agrophytocoenoses in the subzones of middle and south taiga will decrease from 130$180 \mathrm{~mm}$ to $50-70 \mathrm{~mm}$, which will be 5-7 times lower than their minimal moisture capacity (at present, this ratio does not exceed 1.5-1.7). The soil moisture reserves in the zone of mixed forests will fall practically to the same level. By deficit of summer moisture content, sod-podzol soils will approach to the contemporary state of not only gray forest 
soils of broad-leaved forests, but also leached and podzolic chernozems of typical forest-steppe(see Fig. 5). From its part, aridization of gray forest soils will bring them to the state of contemporary meadow chernozems of southern forest-steppe, as well as typical and common chernozems of northern steppe $((\mathrm{W}-100)=30-40 \mathrm{~mm})$. The latter, in their turn, will be aridized towards semidesert chestnut soils.

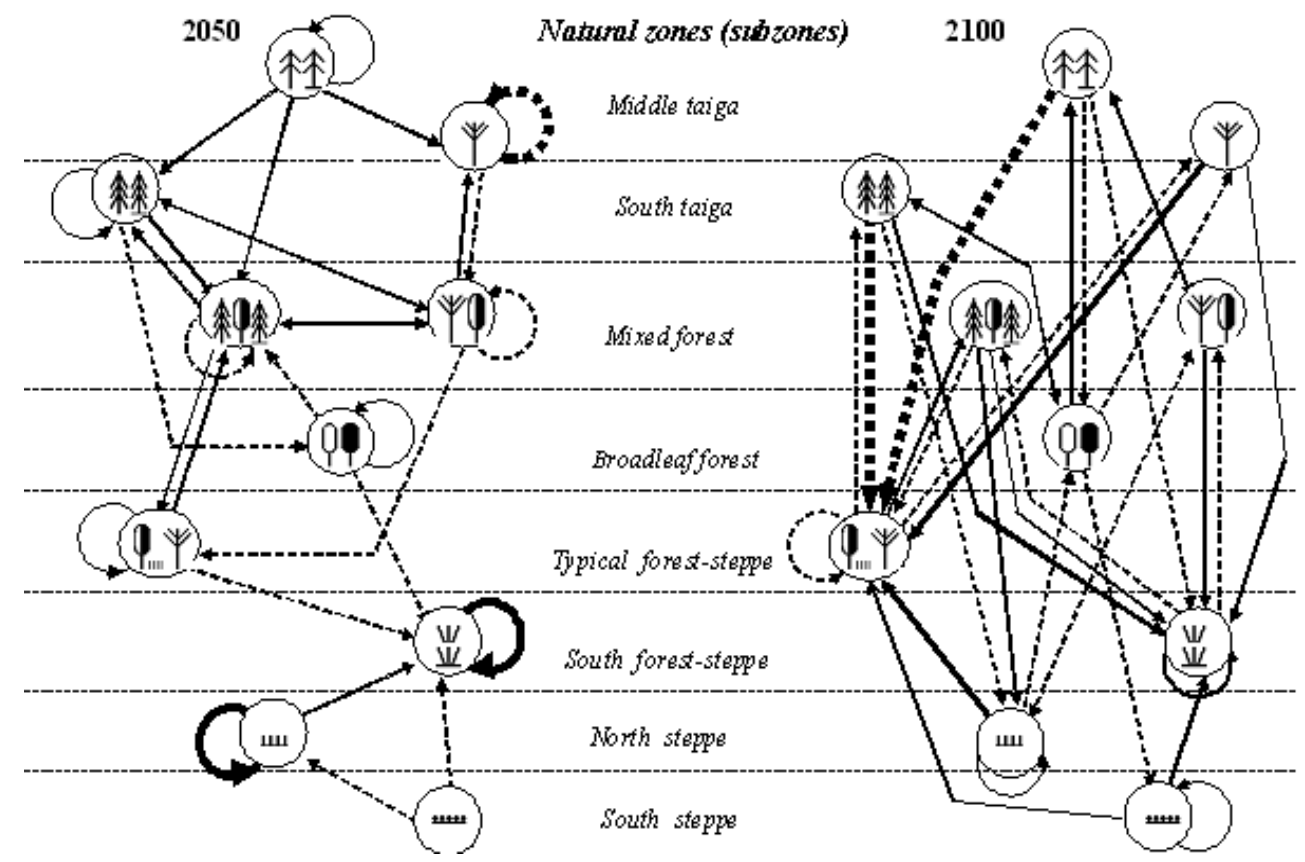

Fig. 5. Vector graphs of the probabilities of functional transitions between the plant formation groups of the headwater of Volga river basin (see in the Supplement II) on the prognostic periods up to years 2050 and 2100, according GISS model. Probabilities of interformation transitions: a - 0.20 and less; $b-0.21-0.30 ; c-0.31-0.40 ; d-0.41-0.50 ; e-0.51-0.60$.

Thus, the conclusion in [77] about the increased soil humidity in continental regions due to the increase of annual precipitation under global warming has not been supported, at least for the Middle Belt of the Russian Plain and in the framework of the prognostic climatic model we have considered. At a decrease of annual atmospheric humidify factor, soil moisture reserves can only reduce, even under increased atmospheric precipitation. The actuality of this fact is confirmed not only by the data presented above but also by the results of many-year stationary observations of soil humidity [86].

The predicted thermo-arid bioclimatic trend will inevitably aggravate the problem of maintenance and reproduction of forest and water reserves, as well as crop growing in the forest-steppe and steppe zones of the Russian Plain. Interpretation of ecological prognosis on the basis of the known effects of soil moisture content in vegetation period on the state of natural plants and agrophytocoenoses [84, 87] leads to the following conclusions.

In 2050, natural reproduction of forest species will have become difficult not only in northern steppe, but also in typical and southern forest-steppe. By 2075, such situation will have occurred also in the subzone of broad-leaved forests. At a decrease of July moisture reserves in 1-m soil layer to $25-30 \mathrm{~mm}$, the viability of mature stands will abruptly decrease, dooming them to dry out. In 20 more years, the critical conditions of reforestation will also spread over the mixed-forest zone.

Agroclimatic conditions will be as unfavorable. In 2050, natural $20-30 \%$ decrease in the yield of cereals should be anticipated in forest-steppe zone at summer $(\mathrm{W}-100)=50$ $70 \mathrm{~mm}$. In 2075-2100, the zone of mixed forests will be in the same conditions, while further decrease of soil moisture reserves in the forest-steppe to a level of $20-35 \mathrm{~mm}$ will cause a yield loss of $40-50 \%$.

It is absolutely evident that global warming already in the nearest decades will cause the demand of additional and quite considerable energy expenses for irrigation in order to maintain the necessary areas of forest stands and crop yields in the Middle Belt of the Russian Plain, where the main cereal belt of European Russia.

\subsection{Prognostic Scenarios of Zonal Structure of the Basin Territory}

As a whole, the orientating graphs (see Figs. 5 and 6) and maps (Figs. 8 and 9) plotted for all two prognostic dates (2050 and 2100) demonstrate a gradual northward shift of zonal and sub-zonal boundaries and the corresponding changes in the types of ecosystem functioning under the action of thermo-arid climatic trend. Objectsdominants and subdominants, whose appearance will be a prototype for transformations of most landscape-zonal systems, will be exclusively sub-boreal natural complexes: typical and southern forest-steppe and northern steppe (see Fig. 5). By 2100, the features of forest-steppe will have become more and more characteristic of not only sub-taiga but also south and middle taiga subzones of the Volga river 
basin.

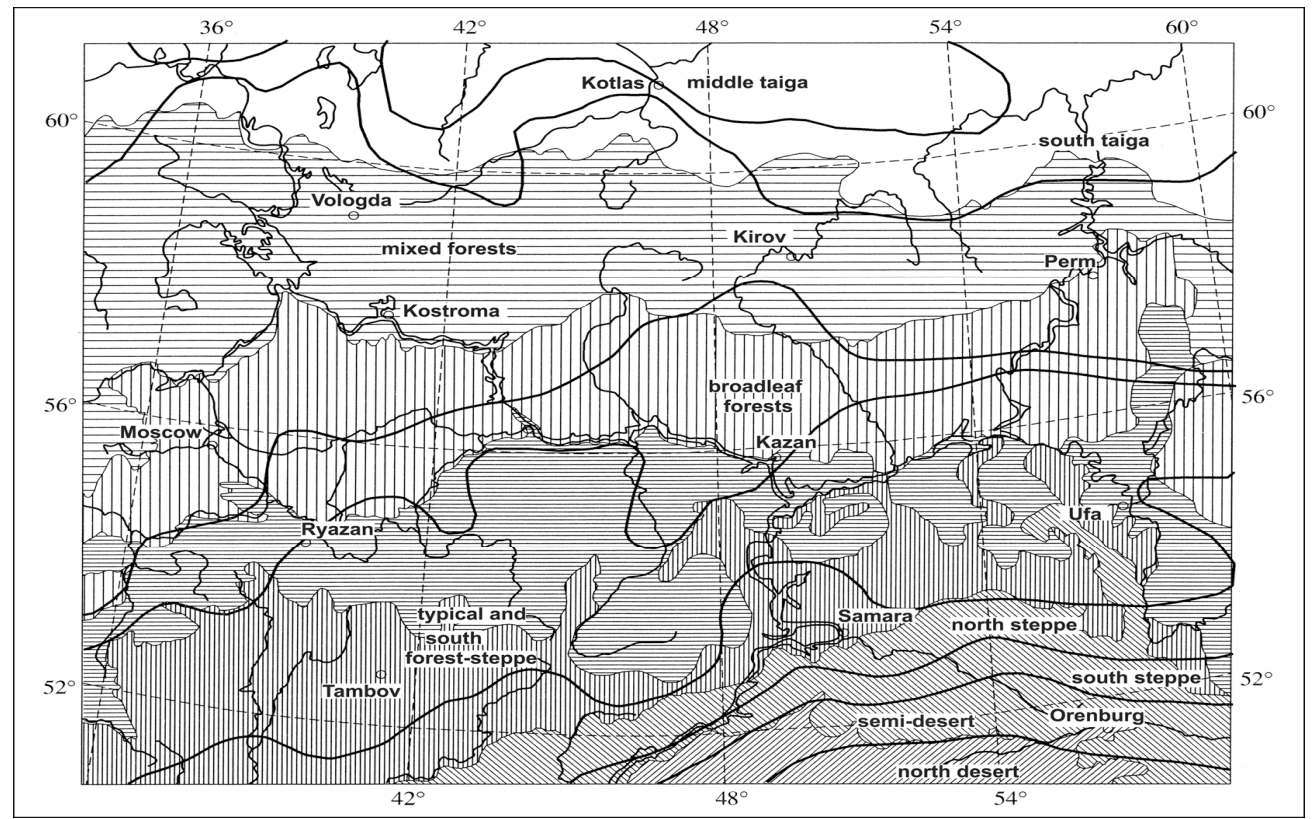

Fig. 9. Prognosis of changes in the landscape-zonal structure of the Volga river basin and its surrounding for the period to year 2075-2100, according to GISS model. Conventions meaning are as in Fig. 8.

The most significant shift of landscape-zonal conditions towards aridization is outlined at the first and second stages of the forecast period, when the increase in atmospheric precipitation will be still low as compared with the temperature increase, which will result in a rather abrupt fall of coefficient of humidification - first in the middle and south taiga and then in the typical and southern forest-steppe. Thus, the starting signal of the warming will be the most effective ecologically and territorially. Already in 2050, the average taiga regime of ecosystem functioning had to be almost completely move to the north, beyond the boundaries of the Volga river basin. Further shifts of landscapezonal boundaries will be much less due to increasing precipitation, particularly in 2100 , slowing down the decrease of $\mathrm{F}_{\text {hum. }}$. Because of this very reason, a counter transgression of the subzones of south and even middle taiga to the territory of broadleaf forests is possible.

Thus, the following equifinal transformations of zonal structure of the Volga river basin may be anticipated. First, two zonal types of the environment will be most developed territorially: mixed forests, on the one hand, and typical and southern forest-steppe, on the other hand. This foreststeppe belt will become broader all along. As we have shown previously [45], the southern boundary of southtaiga subzone is the main climatic border between boreal and sub-boreal belts, because the most abrupt increase in the substance-energy basis of natural complexes is observed here. Consequently, by the middle of the $21^{\text {st }}$ century, almost the whole territory of the main catchment area of the Volga river basin will have occurred in sub-boreal climatic conditions. At the same time, if in the first 30 years the transgression will show itself mostly in the mixed and, to a lesser extent, broad-leaved forests, in the year
2075 the whole forest-steppe zone will be of no less priority and become the predominant absorbing state in the end of the forecast period.

Second, the nemoral subzone will abruptly get narrower and absolutely change its location, having moved beyond the known oro-climatic barrier - a latitudinal segment of the systems of valleys of the Oka, Volga and Kama rivers. The territory of modern broad-leaved forests will be completely absorbed by typical forest-steppe formations (meadow steppe), which partially expand even over the pre-Ural taiga. The oak-lime communities meanwhile will show transgression first to south and then to middle taiga, creating new mixed phytocoenotic structures and thus extending the total area of sub-taiga zone.

Finally, the bioclimatic contrasts in the south-east of the region (in its most continental part) will sharply intensify, which will result in a considerable closing in of zonal and sub-zonal boundaries in the south of by-Ural, up to the appearance of the zone of semideserts at the latitude of Orenburg. The forest-steppe zone will be gradually loosing its stability: the degree of its stabilization from first to third forecast stage would decrease from $50-60 \%$ to $10-20 \%$. Accordingly, it will start to transform into steppe in its southern and particularly southeast regions.

The predicted thermo-arid bioclimatic trend is in harmony with the global scenarios of natural zonality obtained from various models, including the GISS model, for double $\mathrm{CO}_{2}$ concentrations in atmosphere [3,7], i.e., for the year 2100. The maps and schemes plotted by the authors show that the forest-steppe and steppe formations should intrude very deeply into the forest zone of Eurasia, reaching the latitude of the city of Kirov in the east of the Russian Plain and the mouths of the $\mathrm{Ob}$ and Yenisei rivers in Western and 
Central Siberia. At the same time, the farthest expansion of "steppe areals" on the European territory of Russia is anticipated along the Central Russian and Privolzhskaya (ByVolga) Uplands.

Prognosis results, quite similar to our model, have also been obtained for the territory of the former USSR $[8,18]$. This concerns, in particular, significant (2.5-3.4-fold) cutting of the taiga zone anticipated by the $10-30$ s of the $21^{\text {st }}$ century. Moreover, a 10-fold extension of the area of broad-leaved forests seems to be unlikely. We could also agree that by 2050 , when the value of global warming will have reached $1.4^{\circ}$, the landscape-ecological conditions of mixed forests will prevail on the territory of the Volga river basin. According to the calculations [12, 83], the zonal conditions of coniferous/broad-leaved forests are expected to extend to $62-63^{\circ} \mathrm{N}$ in the east of the Russian Plain already in 2010, which goes far beyond the northern boundaries of the Volga river basin. Our scenario, as a matter of fact, assumes such a possibility, but only after the middle of the $21^{\text {st }}$ century.

\subsection{Dynamics of Biological Cycle Parameters in Zonal- Regional Ecosystems}

It is significant to evaluate the possible changes of primary productivity and velocity of forest litter mass decomposition in terrestrial ecosystems are continued by global warming. The prevailing transitions of northern landscapezonal systems into southern systems under the effect of global warming will be accounted for by acceleration of the biological cycle throughout the boreal ecotone, from the middle taiga to the southern forest-steppe. Both the rate of decomposition of dead organic matter, including forest litter, and the level of autotrophic biogenesis will become higher. Therefore, the net primary production of phytocoenoses will increase, entailing additional consumption of soil moisture and mineral nutrients. Now the south-taiga forests have maximum annual $\mathrm{P}_{\text {prim }}(10.5-11.5$ ton/ha per year) and north-steppe formations - minimum one (6-7 ton/ha). According to prognosis calculations primary bioproductivity may rise everywhere on 1.5-2 ton/ha as early as in 2010s in consequence the increase of both temperature and precipitation, and to years of 2050 even at dry steppe it will arrive at 9.5-10.0 ton/ha.

The effect of functional changes will expectedly reach a peak in the eastern sector of the taiga zone (see Tables 8). By the year 2050, the annual rate of increase in the zonal norms of $\mathrm{P}_{\text {prim }}$ in this sector has to be $1.8-2.5 \mathrm{t} /$ ha per $1^{\circ}$ of temperature rise. The increase in precipitation will have an effect mainly in the sub-taiga zone of this sector, where the pluvial gradient of annual $\mathrm{P}_{\text {prim }}$ growth will reach 3.2-3.7 $\mathrm{t} /$ ha per $100-\mathrm{mm}$ increment in the annual amount of precipitation. The initial acceleration of metabolism in the western sector will be lower, but both longitudinal and latitudinal (zonal) differences in the rates of functional activation of boreal forests will gradually level off.

Under the effect of increasing temperature of the warm season, coefficient of annual destruction o forest litter mass (parameter CY) in boreal forests will sharply drop already at the first stage (before 2050). This will indicate a significant increase in the efficiency of the detritus branch of the biological cycle, which is its main limiting component.

Boreal forests of the Volga basin will generally become more productive (in particular, due to the increasing rate of forest litter decomposition). Their annual net production will exceed 13-14 t/ha by the year 2075 and reach $15.5-$ $16.5 \mathrm{t} /$ ha by the year 2100. Following M.I. Budyko [88], it can be figuratively stated that, by the mid-21st century, these forest formations will exemplify the return of the boreal biosphere belt to a more fertile geological epoch in which the concentration of greenhouse gases in the atmosphere was much higher than today.

The calculations showed that already for the period of 2050-2075 the predicted field of $R_{\text {ann }}$ and $I_{\text {arid }}$ will go significantly beyond the limits of their contemporary combinations on the territory of the Russian Plain. The same could be referred to the optimum of Mikulino interglacial period. Within the Volga river basin and adjoining regions at present there are no combinations of high values $R_{a n n}$ (more than 1900-2000 MJ/m²) and very low - $\mathrm{I}_{\text {arid }}$ (below $0.7-0.8$ ), when the productivity of vegetation must exceed the value of 14 ton/ha per year (see Fig. 2.). Such hydrothermal conditions are typical of contemporary humid forest formations of the extreme south of sub-boreal belt and even sub-tropic belt, e.g., Colchis and Lenkoran lowlands, where the annual productivity of forests makes more than 20 ton/ha.

The productivity of boreal forests in the Volga basin will reach the level that, according to published data [62, 89], is equivalent to the lower limit of the present-day productivity of mesophilic meadow steppes and forest-steppes in some well-moistened regions in the extreme south of the Russian Plain (the Azov-Kuban Lowland and the Terek delta) and humid-subtropical liana forests of Transcaucasia. The productivity of broadleaf forests in the middle Volga region, especially that of more xerophilic oak forests, will also approach this level. These data were used for extrapolation prognosis of the primary productivity to dates 2050 and 2100 for natural ecosystems of west and north-west regions of the Volga River Basin. The combinations of predicted $R_{a n n}$ and $I_{a r i d}$ values here exceed the limits of the nomogram on Fig. 2.

A certain growth of net production by the year 2100 (from 8-9 to 11-12 t/ha per year) resulting mainly from the increase in annual precipitation is also expected in phytocoenoses of typical and southern forest-steppes. It will be especially evident at the next stage (between 2050 and 2075) in the western, more humid sector. In the extreme southeast of the region, in northern steppes, tendencies in biological production will be ambiguous. In steppes of the Transvolga and Orenburg regions, a drop of $\mathrm{P}_{\text {prim }}$ is expected due to the unfavorable combination of high values of the annual radiation balance (more than $2050 \mathrm{MJ} / \mathrm{m}^{2}$ ) and the index of aridity (1.7-1.8). 


\subsection{Paleogeographical Reconstructions}

The landscape-zonal map for the Holocene optimum that we have plotted (Fig. 10) as a whole corresponds to the analogous but much finer cartographic data obtained previously for this epoch by other authors for the territory of the Russian Plain [90-92]. As regards the culmination of Mikulino interglacial period, our reconstruction of this epoch (Fig. 11) greatly differs from the known paleogeographical scenario $[58,60,91]$, although we used the point paleoclimatic data from the same work [58]. The mean July temperatures in that epoch on the territory of the Volga river basin and its surroundings were by $0.5-1.0^{\circ}$ higher than today, and in some, mainly western, regions there were zero deviations. At the same time, the annual precipitation was less than today: for $100-120 \mathrm{~mm}$ in the northern belt and for no less than $20-50 \mathrm{~mm}$ in other regions. As we can see, the initial paleoclimatic data primarily determined the thermo-arid trend of deviations of the climatic conditions of the Mikulino optimum from contemporary climate. The main contribution to aridization was made by atmospheric precipitation decrease but not temperature increase.

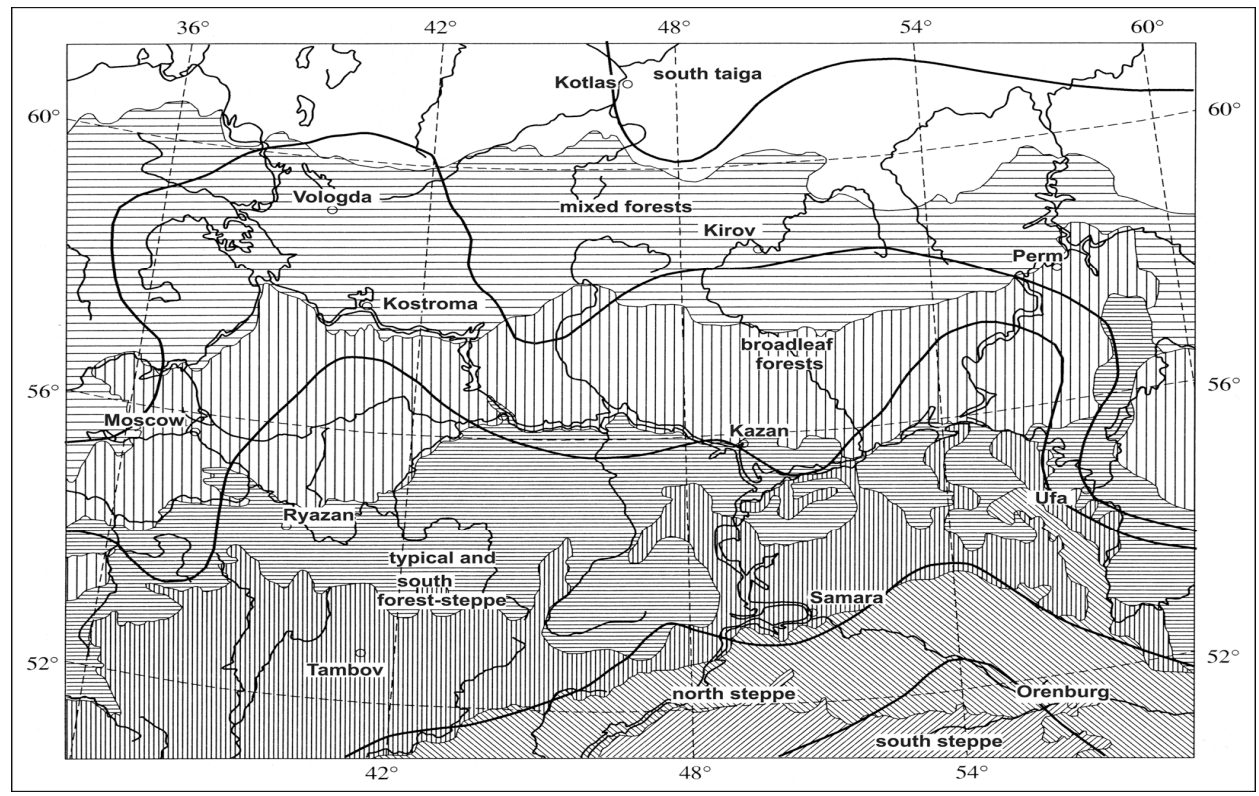

Fig. 10. Zonal landscape-ecological conditions of the Volga river basin and its encirclement for Holocene optimum. Conventions meaning are as in Fig. 8.

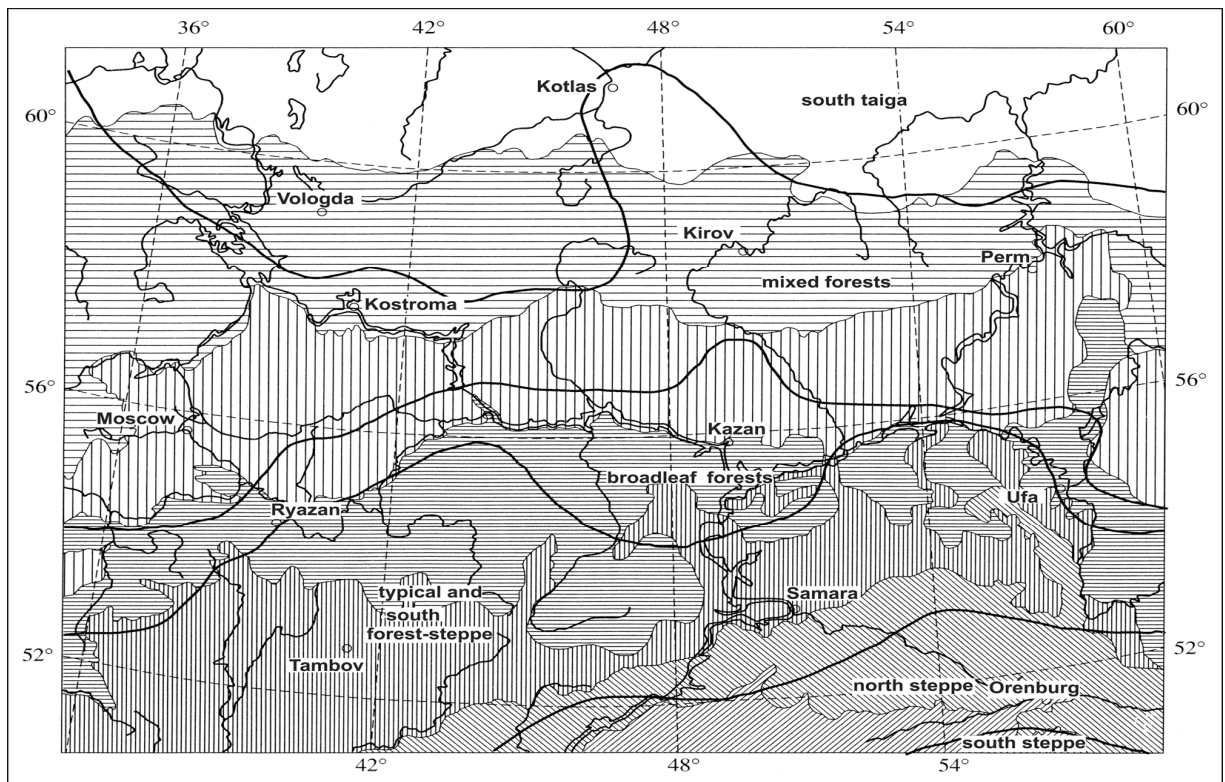

Fig. 11. Zonal landscape-ecological conditions of the Volga river basin and its encirclement for Mikulino interglacial optimum. Conventions meaning are as in Fig. 8.

Both paleogeographical scenarios that we have obtained show an overall shift of zonal and subzonal boundaries in the Middle strip of the Russian Plain to the north as com- pared with their modern location, which would result in the corresponding changes in soil-plant cover structure. Moreover, due to the higher sensitivity to hydrothermal signal of 
the eastern, more continental sector of the Volga river basin, there appears a western addend of boundary movement, and the resulting vector of the shift of natural zones and subzones is directed from southeast to northwest, which is marked by the outlines of zonal boundaries on schematic maps for all prognostic and paleogeographical scenarios.

Thus, one might speak about realization in the two considered epochs of the geological past of a hypothetical thermo-arid trend, i.e., fundamentally similar tendency, which is characteristic of the bioclimatic trend predicted for this territory but with the reverse sign. This very complex hydrothermal feature, but not just temperature similarity, allows consideration of the optima of Mikulino interglacial period and Holocene as paleo-analogs of predicted landscape-ecological situations. Now it turned out that the Mikulino culmination, as compared with the Holocene optimum, was much more acceptable as a paleo-analog of predicted landscape-ecological situation not only for the year 2100 , as it is usually accepted, but also for the whole forecast period.

In both retrospective trends, the "center of gravity" of landscape-ecological deviations shifted towards the southern belt of the main catchment area of the Volga river basin. As absorbing states, there were subboreal ecosystems, which transgressed northwards to occupy the territories of boreal forests. In both paleogeographical sections, foreststeppe played the role of the leading landscape complex, whose structural and functional features showed up to this or that extent nearly in all zonal subdivisions of the south of boreal belt. This decreased a lot the latitude-zonal contrast of the territory and made the entire ecological space of the Volga river basin much more homogenous than at present.

Two paleogeographical phenomena have also been revealed: (1) high stability of the whole polyzonal complex of typical and southern forest-steppe, together with the northern steppe, and nearly complete absorption of the territory of broad-leaved forests by forest-steppe, and (2) steppification of subtaiga characteristic of both paleogeographical sections, more marked in middle Holocene than in Mikulino interglacial period. At the same time, paleogeographical situations were distinguished by much lesser aridity in the north of subboreal belt, beginning from the forest-steppe zone, than it is anticipated in the nearest decades, therefore the location of southern boundaries of Mikulino and middle-Holocene forest-steppe was close to the modern one.

\subsection{Anthropogenic Discrepancy in Retrospective Progno-} sis

When using paleogeographical analogs from the middle Holocene for prognostic purposes, it should be taken into account that these analogs must be applied with certain corrections for anthropogenic changes in the natural zonality, which have taken place on vast European territories in the last 5.5-6 thousand years, from early Stone Age and Bronze Age to the beginning of industrial period (the mid- dle of the $19^{\text {th }}$ century). There is numerous evidence [93] that broadleaf forests in the middle Holocene could spread over the Russian Plain up to the lower reaches of the Dnepr, Don and Volga rivers (at least, by separate "tongues"). During the sub-boreal period of 3-3.5 thousand years, the southern boundary of broad-leaved forests retrieved northwards for 400-600 km under anthropogenic impact (slashand-burn and cattle raising). Indeed, the cold-humid trend of that time displaced the whole system of forest natural zones southwards almost to the same distances (up to 300$500 \mathrm{~km}$ ). Nevertheless, it is quite possible that the system of zonal geospaces of the Russian Plain has come actually to a new quasiequilibrium state under the prolonged impact of man. One of the results of the above is an extreme sinuosity of the contemporary southern boundary of nemoral-forest subzone (see Figs. 6, 8, 9). All subsequent natural changes in plant cover will occur already along the new trajectory, quite different from the one before the neolithic revolution. Consequently, prognostic assessments using the method of actualism are somehow or other based on this new location of zonal boundaries, but not on what would have been in the absence of anthropogenesis.

At the same time, one could hardly agree with the conclusions stated in the works [94] that the modern zonal structure of East Europe has formed only in the last 1-2 thousand years and is a direct result of human activity. These authors think that mixed forests prevailed there in middle Holocene. Moreover, it is stated that the transformation of soil-plant cover induced by agriculture caused abrupt changes in the climate of the whole subcontinent.

Without going into discussion as to the correctness of chronological interpretation of paleomaterials by the authors, let us offer the results of geophysical calculations for northern Podmoskovye belonging to the zone of mixed forests $\left(\mathrm{F}_{\text {hum }}=1.5\right)$. The calculations have been made by the data from [45] and are based on the results of the study by Yu. L. Rauner [87]. It turned out that the elimination of dark-coniferous forest plants results in a decrease of $F_{\text {hum }}$ for $0.13-0.17$, and reduction of leaf forest - for $0.06-0.07$. Such shifts in the warmth to moisture ratio towards aridization might be of great ecological significance only close to zonal or subzonal boundaries, however they cannot cause transition of the entire landscape-zonal system from one category to another. In this case, northern Podmoskovye will remain in the zone of mixed forests even if the percentage of forest land in it is only several per cent, as it was, e.g., on the territory of Central Russia in the $21^{\text {th }}$ century, in the period of massive plowing up.

\section{Conclusion}

The main substance of the report is a systems analysis of boreal and sub-boreal ecosystems of zonal-regional level and prediction of their states under conditions of forthcoming global climate changes. On principal new, landscapeecological approach to the decision of the all complex of prognostic problems has been realized in given work. 
Landscape-ecological models that we develop for the boreal ecotone of European Russia, characterize regional natural territorial mosaics, and rules of organization of such mosaics in space and time. The type of the models is empirical-statistical, since they are based on direct observations and measurements in nature, cartographical and remote sensing data. It is presented the regional paleoprognostic ecological-geographical conception, describing the landscape-ecological scenarios of the nearest future of terrestrial nature complexes and their paleogeographical analogs as a single system of global changes in the environment.

The boreal bioclimatic ecotone of the Volga river basin is used as an example for consideration of theoretical and scientific-methodical problems of geographical zonality - a fundamental ecologo-geographical conception at the present-day stage of biosphere evolution associated with the global anthropogenic impact on the climate. The predicted thermo-arid bioclimatic trend will inevitably aggravate the problem of maintenance and reproduction of forest and water reserves, as well as crop growing in the foreststeppe and steppe zones of the Russian Plain. The assessment of anthropogenic impact on natural ecosystems requires rather deep knowledge of natural processes and events which are a substance-energy basis of interaction of man and nature. This very basis has been considered in the present work.

Obtained results are not only of scientific and/or methodical interest. They obviously will have certain practical significance also for the economic regions of forest and forest-steppe zones of the Volga River basin. The data on the condition of forest and forest-steppe ecosystems and prognostic assessments of their forthcoming changes may be used to develop the bases of preservation, reproduction and rational use of forest (and accordingly water) resources, to form a network of protected and recreational territories (nature reserves, wildlife refuges, national parks), which is particularly important for the regions with critical existence conditions for vegetation, including the zone of forest-tosteppe contact.

\section{References}

[1] V.M. Kotlyakov, "Geographiya i vyzhivanie chelovechestva”, Izvestiya. RAN, Seriya Geographicheskaya, 1992, № 2, pp. 8-14 (in Russian).

[2] M.I. Budyko, Klimat i zhizny. Leningrad: Gidrometeoizdat, 1971 (in Rassian).

[3] R. Leemans, "Modelling ecological and agricultural impacts of global change on a global scale". J. of Sci. \& Industrial Res. 1992, vol. 51, pp. 709-724.

[4] L.G. Houghton, L.G. Meira Filho, B.A. Callander (Eds.), Climate Change 1995. The Science of Climatic Change. Cambridge, UK: Cambridge Univ. Press, 1996.

[5] I.P. Gerasimov, Ecologicheskie problemy v proshloy, nastoyashchey i budushchey geographii Mira. Moskva: Nauka,
1985 (in Russian).

[6] V.B. Sochava, Vvedenie v uchenie o geosistemah. Novosibirsk: Nauka, 1978 (in Russian).

[7] W.R. Emanuel, H.H. Shugart, \& M.R. Stevenson, "Climatic changes and the boreal-scale distribution of terrestrial ecosystem complexes”, Climatic Change. 1985, № 7, pp. 29-43.

[8] K.I. Kobak, N.Yu. Kondrasheva, N.Yu., "Globalynoe poteplenie i prirodnye zony", Meteorologiya i gidrologiya. 1992, № 8, pp. 91-98.

[9] T.M. Smith, R. Leemance and H.H. Shugart, "Sensitivity of Terrestrial Carbon Storage to $\mathrm{CO}_{2}$-Induced Climate Change: Comparison of Four Scenarios Based on General Circulation Models", Climatic Change. 1992, vol. 21, pp. 367-384.

[10] O. D. Sirotenko, E.V. Abashina, "Agroklimaticheskie resursy i fiziko-geographicheskaya zonalnosty territorii Rossii pri globalnom poteplenii", Meteorologiya i gidrologiya, 1998, № 3, pp. 92-103 (in Russian).

[11] A.A. Velichko, O.K. Borisova, E.M. Zelikson, V.P. Nechaev, "Permafrost and vegetation response to global warming in North Eurasia", in: G.M. Woodwell and F.T. Mackenzie (Eds.).Biotic Feedbacks in the Global Climate System. Will Warming Feed the Warming? New York, Oxford: Oxford University Press, 1995, pp. 134-156.

[12] A.A.Velichko, O.K. Borisova, E.M. Zelikson, T.D. Morozova, "Changes in vegetation and soil of the East European Plain to be expected in the $21^{\text {th }}$ century due to anthropogenic changes in climate", Geographic Polonica, 2004, vol. 77, № 2, pp. 35-45.

[13] I.I. Mokhov, J.-L. Dufrense, H.Le. Trent, "Changes in drought and bioproductivity regimes in land ecosystems in regions of Northern Eurasia based on calculations using a global climatic model with carbon cycle", Doklady Earth Sciences, 2005, vol. 405 A, № 9, pp. 1414-1418.

[14] M.A. Glazovskaya, Geohimicheskie osnovy tipologii i metodiki issledovany prirodnyh landshaftov. Moskva: Izdatelstvo MGU, 1964 (in Russian).

[15] B.J. Chorley, B.A. Kennedy, Physical Geography. A System Approach. London: Prentice-Hall, 1971.

[16] F.N. Milkov, Fizicheskaya geografiya: sovremennoe sostoyanie, zakonomernosti, problemy. Voronezh: Izdatelystvo. Voronezh. Univers., 1981 (in Russian).

[17] A.D. Armand, "Sharp and gradual timberlines as a result of srecies interaction", in: A.J. Hansen, F. di Castri (Eds.). Landscape Boundaries. Consequences for biotic diversity and Ecological Flows. New York Berlin Heidelberg: Springer-Verlag, 1992, pp. 360-378.

[18] K.I. Kobak, N.Yu. Kondrasheva, \& I.E.Turchinovich, "Vliyanie izmeneny climata na prirodnuyu zonalnocty i ecosistemy Rossii", in: G.V. Menzhulin (Ed.). Izmeneniya klimata $i$ ih posledstviya. Sankt-Peterburg: Nauka. P. 205210 (in Russian).

[19] A.A. Velichko, B. Frenzel, M. Pesci (Eds.). Atlas of Paleoclimates and Paleoenvironments of the Northern Hemisphere. Late Pleistocene - Holocene. Budapest: Geogr. Res. Inst. Hungar. Academy of Sci., 1991.

[20] A.A.Velichko (Ed.), Climates and landscapes of northern 
Eurasia under conditions of global warming. Retrospective analysis and scenarios. Moskva: GEOS, 2010 (in Russian).

[21] M.I. Budyko, M.C. Makkraken, Yu.A. Izrael, A.D. Khect (Eds.), Predstoyashchie izmeneniya klimata. Leningrad: Gidrometeoizdat, 1991 (in Russian).

[22] V.V. Dokuchaev, Uchenie o prirodnyh zonah. Moskva: Geographgiz, 1948 (in Russian).

[23] A.A. Grigoryev, Zakonomernosti stroeniya i razvitiya geographicheskoy sredy. Moskva: Mysly, 1966 (in Rus-sian).

[24] H. Walter, Allgemeine Geobotanik. Eine kurze Einführung. Stuttgart: Verlag Eugen Ulmer, 1979.

[25] V.V. Dokuchaev, Izbrannye sochineniya. T. III. Kartographiya, genesis i klassifikatsiya pochv. Moskva: Gos Izdat-vo selyskohoz. literatury, 1949 (in Russian).

[26] L.S. Berg, Klimat i zhizny. Moskva: Geographgiz, 1947 (in Russian).

[27] G.D. Richter, "Zonalynosty i sistema taxonomicheskih edinits physiko-geographicheskogo rayonirovaniya", Izvestiya AN SSSR. Ser. geographich., 1965, № 5, pp. 3-15 (in Russian).

[28] V.R. Volobuev, Systema pochv Mira. Baku: Elm, 1973 (in Russian).

[29] F.N. Milkov, Fizicheskaya geografiya: Uchenie o landshafte i geograficheskaya zonalynocty. Voronezh: Izdatelystvo Voronezh. Univers., 1986 (in Russian).

[30] R.G. Bailey, Ecoregions, The Ecosystem Geography of the Oceans and Continents. New-York: Springer-Verlag, 1998.

[31] L.S. Berg, Izbrannye trudy. Vol. 2. Phizicheskaya geographiya. Moskva: Izd-vo AN SSSR, 1958 (in Russian).

[32] D.L. Armand, Nauka o landshafte. Moskva: Mysly, 1975 (in Russian).

[33] N.I. Bazilevich, O.S. Grebenshchikov, A.A. Tishkov, Geographicheskie zakonomernosti struktury i funktcionirovaniya ecosystem. Moskva: Nauka, 1986 (in Russian).

[34] A.A. Grigoryev, Tipy geographicheskoy sredy. Moskva: Mysly, 1970 (in Russian).

[35] A.A. Krauklis, Problemy eksperimentalynogo landshaftovedeniya. Novosibirsk: Nauka, 1979 (in Russian).

[36] I. Berton, "Globalynoe poteplenie i rayony ustoychivosti", in: N.F. Glazovsky (Edit.), Globalynye izmeneniya i regionalynye vzaimosvyazi, Moskva: Institute geographii AN SSSR, pp. 65-97 (in Russian).

[37] D.L. Armand, V.S. Preobrazhensky, A.D. Armand, "Prirodnye kompleksy I sovremennye metody ih izucheniya", Izvestiya AN SSSR, Seriya geographich., 1969, № 5, pp. 5-16 (in Russian).

[38] K. Raman, "Opyt ponimaniya geokompleksa kak prostranstvenno-polistrukturnogo edinstva, in: Mezhdunarodnaya geografiya-76. Obshchaya fizicheskaya geografiya, Moskva: Mezhdunarod. Geogr. Congress, 1976, pp. 18-22 (in Russian).

[39] N.A. Solntsev, "V zashchitu zakona Dokuchaeva", in: N.A. Solntsev N.A. (Edit.), Landshaftny sbornik. Moskva: Iz- da- telstvo MGU, 1973, pp. 5-28 (in Russian).

[40] V.B. Sochava, Rastitelny pokrov na tematicheskikh kartakh. Novosibirsk: Nauka, 1979 (in Russian).

[41] I.N. Gartsman, "Problemy geographicheskoy zonalynosti i diskretnosty gidrometeorologicheskih poley $\mathrm{v}$ gornyh usloviyah mussonnogo klimata", Trudy DVNIGMI, 1971, vol. 35, Leningrad: Gidrometeoizdat, pp. 3-31 (in Russian).

[42] Eu. P. Odum, Fundamentals of Ecology. Third edition. Philadelphia-London-Toromto: W.B. Saunders Company, 1971.

[43] E.G. Kolomyts, "Forests on the Boreal Ecotone of the Russian Plain and them Carbon Balance under Global Warming: Experience of Predictive Modeling", Advances in Environmental Research, 2011, vol. 22, New York: Nova Science Publishers, Inc., pp. 1-62.

[44] E.G. Kolomyts, Regionalnaya model globalnyh izmeneniy prirodnoy sredy. Moskva: Nauka, 2003 (in Russian, Abstract by English, pp. 306-318).

[45] E.G. Kolomyts, Borealyny ecoton i geographicheskaya zonalynosty. Atlas-monographiya. Moskva: Nauka, 2005 (in Russian).

[46] E.G. Kolomyts, Forest ecosystems and global climate changes: Experience of predictive modeling. Saarbrüken, Germany: LAMBERT Academic publishing, 2012.

[47] G.B. Bonan, D. Polland \& S.L. Thompson, "Effect of boreal forest vegetation on global climate warming", Nature, 1992, vol. 359, pp. 716-718.

[48] J.I. Holten, G. Paulsen, W.C. Oechel (Eds.), Impacts of climatic change on natural ecosystems (with emphasis on boreal and arctic/alpine areas). Trondheim: NINA and DN, 1993.

[49] A.S. Komarov, O.G. Chertov, S.L. Zudin, "EFIMOD 2 - a model of growth and elements cycling of boreal forest ecosystems", Ecol. Modell., 2003, vol. 170, pp. 373-392.

[50] A.M. Tarko, Antropogennye izmeneniya globalnyh biosfernyh protsessov. Matematicheskoe modelirovanie. Moskva: Phizmatlit, 2005 (in Russian).

[51] G.S. Rozenberg, Modeli v phytocenologii. Moskva: Nauka, 1984 (in Russian).

[52] H. Walter, Die vegetation der Erde: in öko-physiologischer Betrachtung. Bd. II. Die gemäßigten und arctischen Zonen. Jena: Veb Gustav Fischer Verlag, 1968.

[53] R.H. Whittaker, Communities and Ecosystems. New-York: Macmillan Publishing Co., Inc., 1975.

[54] A.G. Isachenko, Landshafty SSSR. Leningrag: Izdatelystvo LGU, 1985 (in Russian).

[55] V.N. Sukachev, Izbrannye trudy, vol.1, Osnovy lesnoy tipologii i biogeocenologii. Leningrad: Nauka, 1972 (in Russian).

[56] T.V. Kotova (Ed.) Rustitelnosty evropeyskoy chasty SSSR i Kavkaza. Map. M-b 1:2,000,000. Moskva: GUGK, 1987 (in Russian).

[57] M.I. Budyko, Klimat v proshlom i budushchem, Leningrad: Gidrometeoizdat, 1980 (in Russian). 
[58] A.A. Velichko, V.P. Grichuk, E.E. Gurtovaya, E.M. Zelikson, "Paleoklimat territorii SSSR v optimum poslednego (mikulinskogo) mezhlednikovya" Izvestiya AN SSSR. Seriya geographich., 1983, № 6. pp. 30-45 (in Russian).

[59] A.A. Velichko, V.A. Klimanov, "Klimaticheskie usloviya Severnogo polushariya 5-6 tysach let nazad", Izvestiya AN SSSR, Seriya. geographich., 1990, № 5. pp. 38-52 (in Russian).

[60] A.A. Velichko (Ed.), Izmenenie klimata i landshaftov za poslednie 65 millionov let, Moskva: GEOS,. 1999 (in Russian).

[61] N.I. Koronkevich, Vodny balans Russkoy ravniny i ego antropogennye izmeneniya, Moskva: Nauka, 1990 (in Russian).

[62] N.I. Bazilevich, L.E. Rodin, "Geographicheskie zakonomernosti produktivnosti i krugovorota khimicheskih elementov v osnovnyh tipah rastitelynosti Zemli", in: Obshchie teo- reticheskie problemy biologicheskoy produktivnosti, Leningrad: Nauka, 1971. pp. 24-33.

[63] N. I. Bazilevich, Biologicheskaya produktivnosty ekosistem Severniy Evrasii, Moskva: Nauka, 1993 (in Russian).

[64] S.E. Wompersky (Ed.), Biologicheskaya produktivnosty lesov Povilzhya. Moskva: Nauka, 1982 (in Russian).

[65] G. Kustler, "ABC of information theory", in: Hubert P. Yockey (Ed.), Information theory in biology. London New-York - Los Angeles: Pergamon Press, 1957, pp. 5-48.

[66] Yu.G. Puzachenko, and V.S. Skulkin, Struktyra rastitelnosti lesnoy zony SSSR, Sistemny analiz. Moskva: Nauka, 1981 (in Russian).

[67] W.R. Ashby, An Introduction to Cybernetics. London: Oxford University Press, 1956.

[68] I.M. Zeydis, V.I. Kruzhalin, Yu.G. Simonov, "Obshchie svoystva dinamiki geoisistem" Vestnik MGU. Seriya 5, Geographiya, 2001, № 4, pp. 3-8 (in Russian).

[69] Yu.G. Puzachenko, Metodologicheskie osnovy geographicheskogo prognoza i okhrany sredy. Moskva: Izdatelstvo URAO, 1998 (in Russian).

[70] V.L. Andreev, Klassifikatsionnye postroeniya v ekologii i sistematike. Moskva: Nauka, 1980 (in Russian).

[71] A.K. Mitropolsky, Tekhnika statisticheskih vychisleniy. Moskva: Nauka, 1971.

[72] Yu. A. Izrael (Ed.), Otsenki ekologicheskih i sotsialnoekonomicheskih posledstviy izmeneniy klimata. Doklad Rabochey gruppy II MGEIK. Sankt-Peterburg: Gidrometeoizdat, 1992 (in Russian).

[73] Yu. A. Izrael (Ed.), Sostoyanie i komplexny monitoring prirodnoy sredy i klimata, Predely izmeneniy. Moskva: Nauka, 2001 (in Russian).

[74] E.S. Rubinshteyn, L.G. Polozova, Sovremennye izmeneniya klimata. Leningrad: Gidrometeoizdat, 1966 (in Russian).

[75] J.G. Hansen, I. Hung, A. Lasis A, "Global Climate Changes as Forecasted by Goddard Institute for Space Studies ThreeDimentional Models", J. Geophys. Res., 1988, vol. 92. pp. 9341-9354.
[76] N.A. Lemeshko, "Gidrologichesky rezhim sushi pri udvoenii contsentratsii uglekislogo gaza $v$ atmosphere", in: Izmeneniya klimata $i$ ih posledstviya, Sankt-Peterburg: Nauka, 2002, pp. 251-259 (in Russian).

[77] G.V. Menzhulin, S.P. Savvateev, "Mirovaya prodovolystvennaya problema i sovremennoe globalynoe poteplenie", in: M.I. Budyko (Ed.), Izmeneniya klimata i ego posledstviya, Sanktpeterburg: Nauka, 2002, pp.122-151 (in Russian).

[78] B. Santer, "The use general circulation models in climate impact analysis - a preliminary stay of the impacts of a $\mathrm{CO}_{2}$ - indicated climatic change on west european agriculture", Climatic Ghanges, 1985, vol. 7, № 1, pp. 71-93.

[79] T.M. Smith \& H.H. Shugart, "The transient response of terrestrial carbon to perturbed climate", Nature, 1993, vol. 361, № 6412, pp. 523-526.

[80] D.L. Albritton, T. Barker, I. "Bashmakov, Izmenenie klimata, 2001", in: R.T. Whotson (Ed.), Oboshchenny doklad MGEIK, Geneva: World Meteorogical Organization, 2003 (in Russian).

[81] A.V. Kislov, "Izmeneniya i izmenchivosty globalynogo klimata", in: N.S. Kasimov (Ed.). Sovremennye globalynye izmeneniya prirodnoy sredy, Moskva: Nauchny mir., 2006, vol. I, pp. 118-129 (in Russian).

[82] M.I. Neyshtadt, Istoriya lesov i paleogeografiya SSSR v golotsene. Moskva: Izdatelystvo AN SSSR, 1957 (in Russian).

[83] A.A. Velichko, "Zonalynye i makroregionalynye izmeneniya landshaftno-klimaticheskih usloviy, vyzvannyh "parnikovym effektom". Izvestiya RAN, Seriya geographich., 1992, № 2, pp. 89-101 (in Russian).

[84] S.A. Verigo, L.A. Razumova, Pochvennaya vlaga (primenitelyno $\mathrm{k}$ zaprosam selyskogo khosyaystva), Leningrad: Gydrometeoizdat, 1973 (in Russian).

[85] I.I. Borzenkova, V.A. Zubakov, A.G. Lapenis, Rekonstruktsiya globalynogo klimata tyoplyh epoh proshlogo", Meteorologiya i gidrologiya, 1992, № 8, pp. 25-37 (in Russian).

[86] I.I. Sudnitsin, M.M. Sidorova, N.S. Oreshkin, M.I. Vasilyeva, "Vliyanie meteorologicheskih usloviy na izmenenie zapasa vlagi $\mathrm{v}$ dernovo-podzolistoy suglinistoy pochve", Meteorologiya i gidrologiya, 1988, № 8, pp. 90-99 (in Russian).

[87] Yu.L. Rauner, Teplovoy balans rastitelynogo pokrova. Leningrad: Gidrometeoizdat, 1972 (in Russian).

[88] M.I. Budyko, "Globalynoe poteplenie", in: M.I. Budyko (Ed.), Izmeneniya klimata $\mathrm{i}$ ego posledstviya, SanktPeterburg: Nauka, 2002, pp. 7-12 (in Russian).

[89] N.V. Dumitrashko (Ed.), Kavkaz. Prirodnye usloviya i estestvennye resursy SSSR. Moskva: Nauka, 1966 (in Russian).

[90] K.K. Markov, T.A. Burashnikova, M.V. Muratova, I.A. Suetova, "Klimaticheskaya model i geograficheskie zony vremeny golotcenovogo optimuma na territorii SSSR", in Antropogennye factory $\mathrm{v}$ istorii razvitiya sovremennyh ekosistem, Moskva: Nayka, 1981, pp. 230-240 (in Russian). 
[91] I.P. Gerasimov, A.A. Velichko (Eds.), Paleogeografiya Evropy za poslednie sto tysyach let (Atlas-mionografiya). Moskva: Nauka, 1982 (in Russian).

[92] I.V. Ivanov, A.A. Velichko, T.D. Morozova, "Osnovnye cherty pochvennogo pokrova Vostochnoy Evropy $\mathrm{v}$ atlantichesky period golotsena", Doklady. RAN, 1994, vol. 337, № 5, pp. 667-671 (in Russian).

[93] M.A. Guman, N.A. Khotinsky, “Antropogennye izmene- niya rastitelynosti tsentra Russkoy ravniny v golotsene (po palinologicheskim dannym)", in: Antropogennye factory $\mathrm{v}$ istorii rasvitiya sovremennyh ecosystem, Moskva: Nauka, 1981. pp. 7-19 (in Russian).

[94] O.V. Smirnova, A.N. Turubanova, M.V. Bobrinsky, "Rekonstruktsiya istorii lesnogo poyasa Vostochnoy Evropy i problema podderzhaniya biologicheskogo raznoobraziya", Uspehy sovremennoy biologii, 2001, № 2, pp. 144-159 (in Russian). 